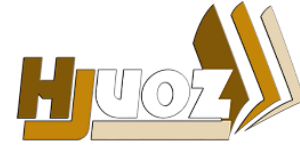

hjuoz.uoz.edu.krd p-ISSN: 2410-7557
كَوّارا زانستيّن مروّقايهتى يا زانكوّيا زاخوّ

مجلة العلوم الانسانية لجامعة زاخو

Humanities Journal of University of Zakho (HJUOZ)

Vol. 4, No. 3, pp. 522-540, December-2016

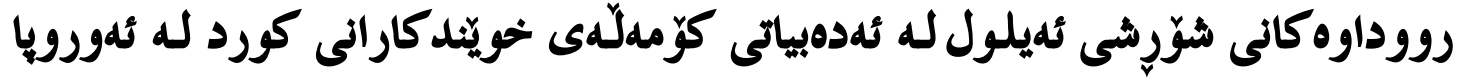

\section{$197 \cdot-1971$}

\author{
ندوز اد عدلى ئهمدد \\ راويّز كار له بهرلدمانى كوردستان نهان
}

https://doi.org/10.26436/2016.4.3.288

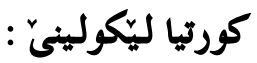

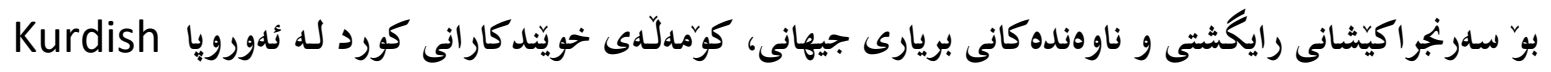
Students Society In Europe

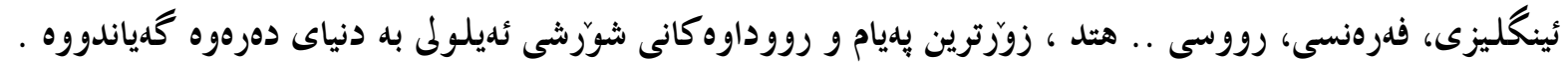

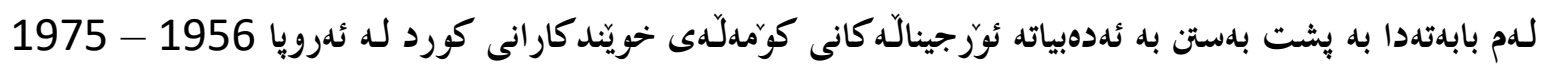

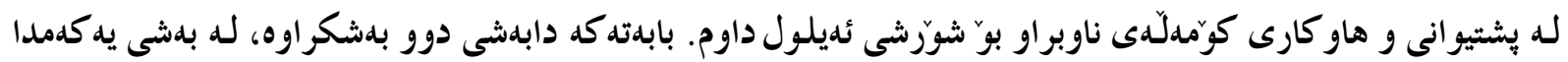

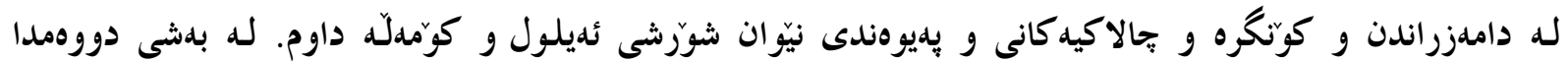

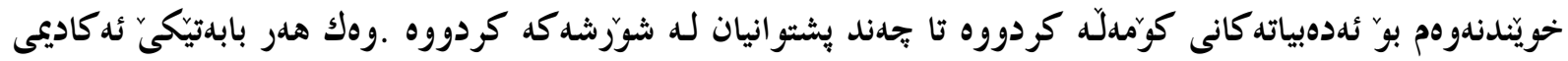

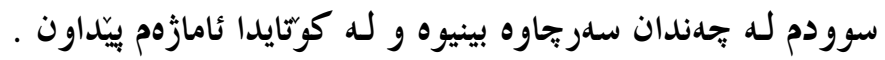

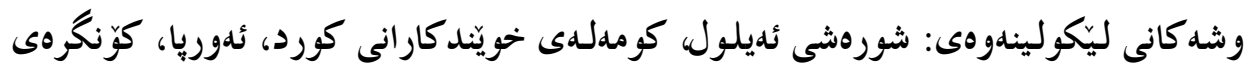

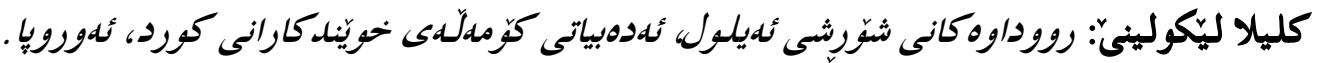

دهستدهكون. ئدم باسهى منيش ئيشكردنه للهسهر

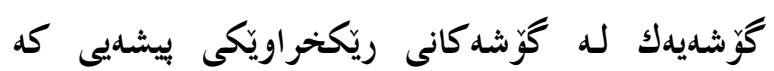

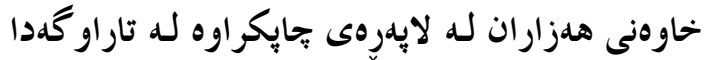

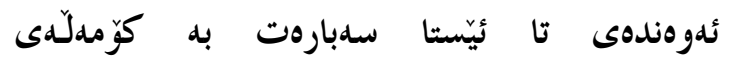

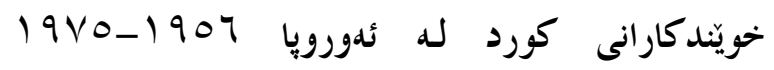
نووسراوه، رهنگه يُكى شيّر بهر من بكدويّت، بدلّام

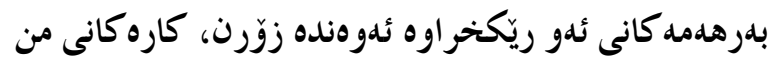

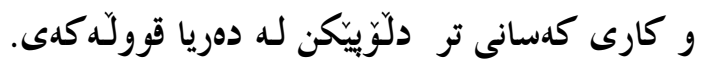

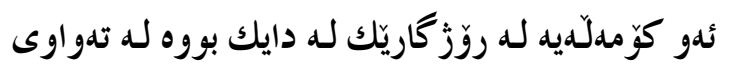

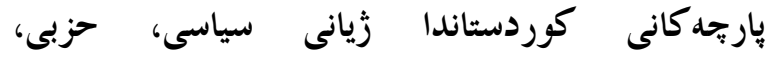

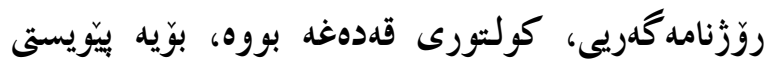

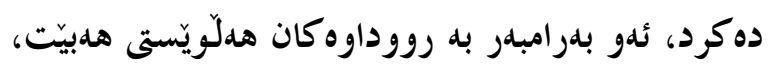

نووسهر و شارهزا و يُسيوّرانى كورد به گُويّرهى

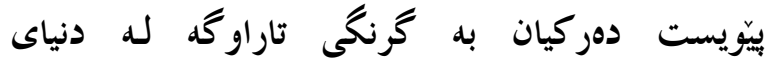

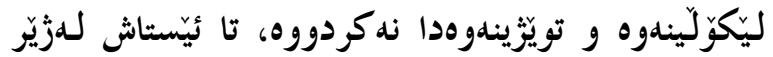

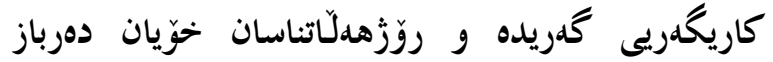

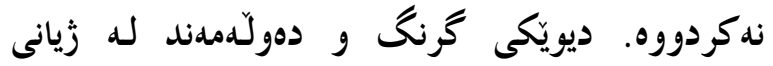

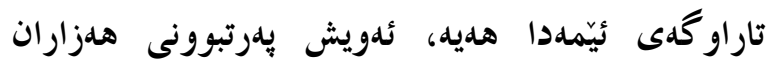

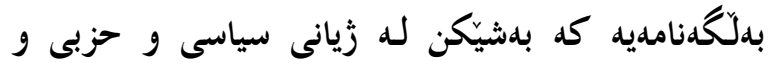
ريّكخر اوهيى نهتهو كمدمان.

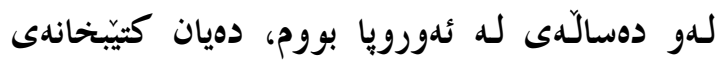
شهخسى، ئهرشيث و كتيبِخانه دهولَّتييل كانم بينى جوَرهها

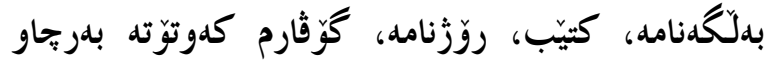

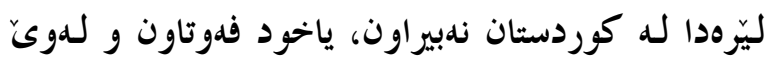




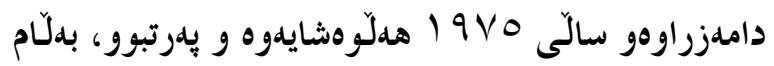

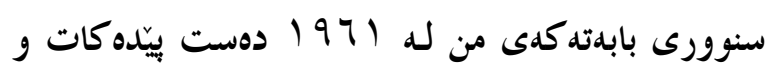

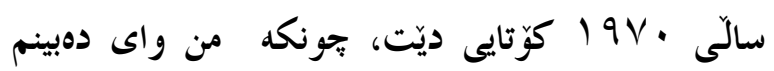

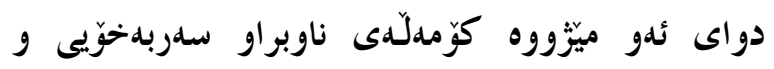

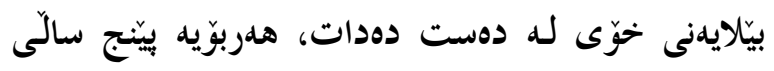

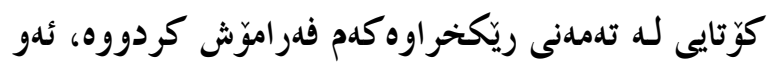

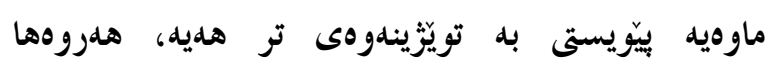

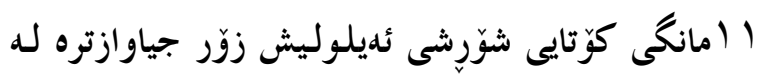

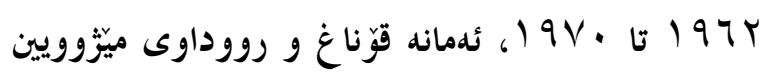
بيّزّيسته به كهرهسته و بوّاجوونى جياوازتر كاريان للهسهر

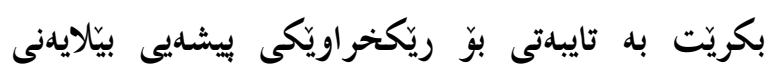

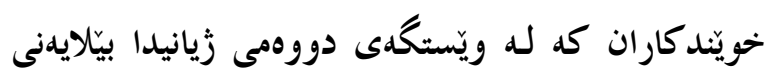
خوّى له دهست دابيّت! ووك هلر بابهتيّكى ئهكاديمى لله كوّتاييدا بوختهى

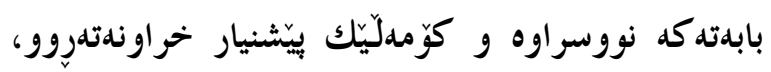

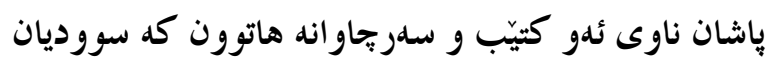
ليّوهر كيراوه.

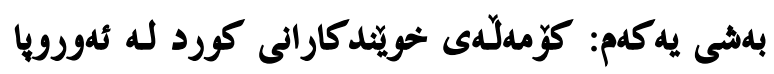
و شوّرِّى ثلديلول سلرهتاكانى كوّهى كورد بوّ دهرهوه:

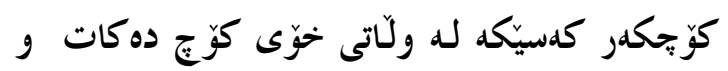

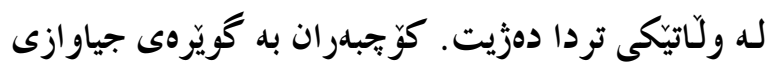

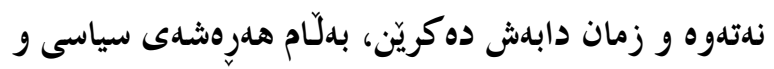

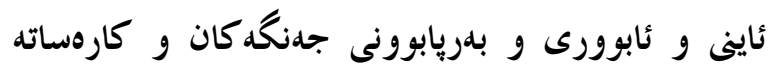
سرووشتييد كان هوّ كارن بوّ كَّ بِكردن.

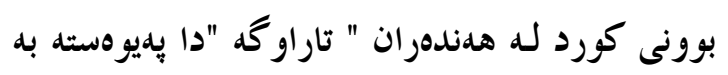
رووداوهكانى ناوخوّى كوردستان و كاريگهدرييان لـهسهر

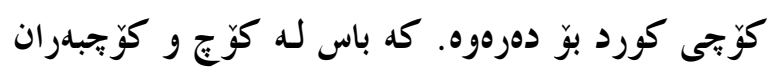

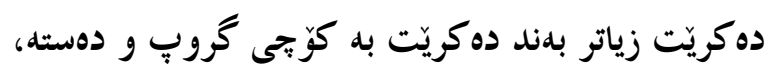

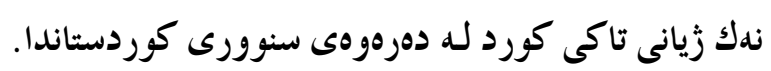

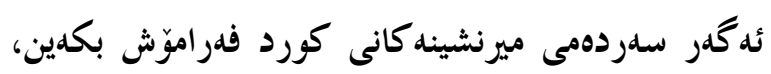

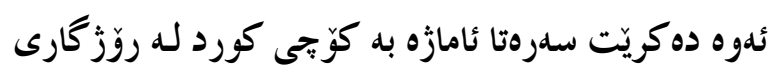

به تايبهتيش لـه لايهن دهستهبُّيَّيَك دامهزرا و له كوّميتهى

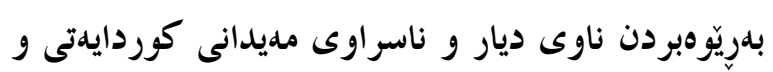
كوردهوارى هدبورن. ئهم باسهى منيش"رووداوه كانى شوّرشى ئديلول لـه

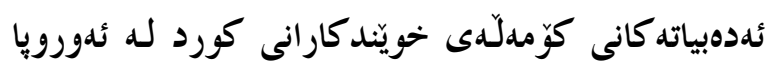

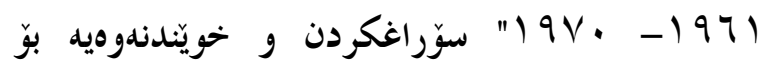

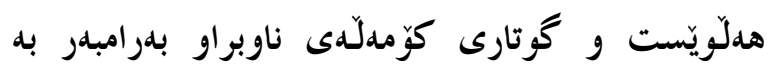

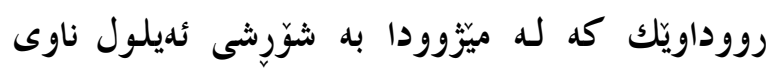
هاتووه.

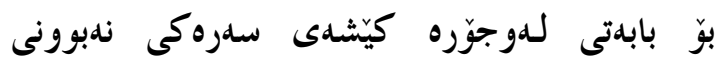

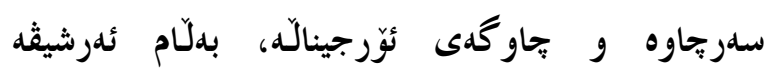

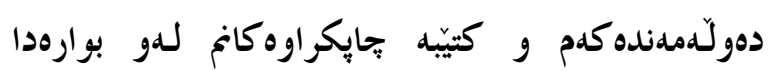
كمميّك بارى سهرشانيان سووك كردم، ئدوهى ماندووم

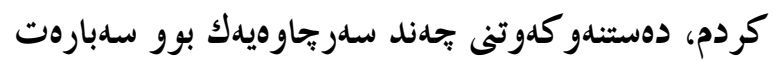
به بيروّكهى دامهزراندنى پارتى ديموكراتى كوردستانى

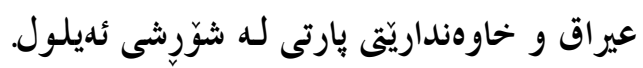

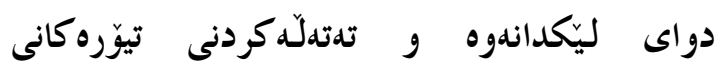

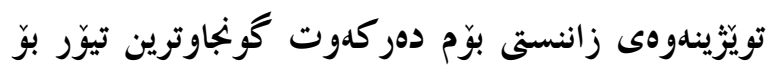

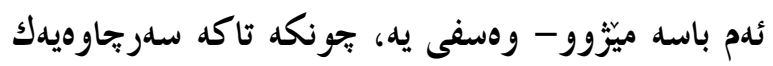

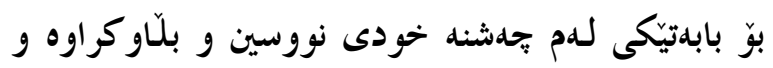

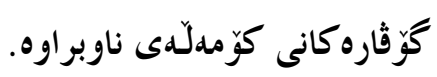
ئهم بابهته دابهشى دوو بلهشكراوه:

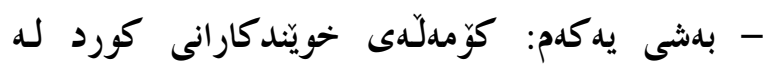
ئدوروبا و شوَرِّى ئديلول

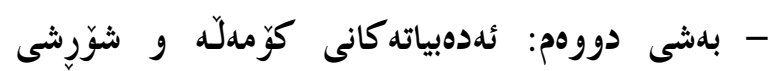
ئديلول بوّ دوّزينهوهى وولّامى درووست هلَّر يدكيّك لـهم

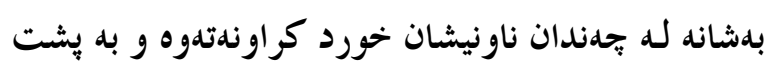

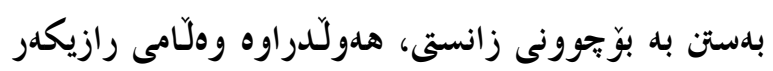

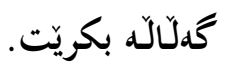

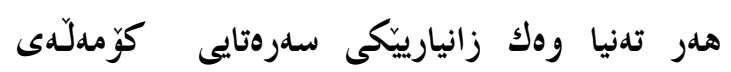
خويّندكارانى كورد لـه ئدورويا له سله سالّى 1907 
كوردستان كردبيّت بريتى بوون له روّشنبيرو

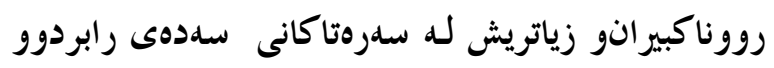

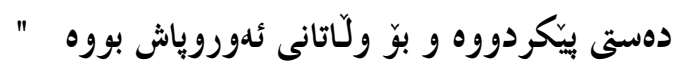

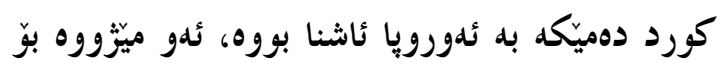

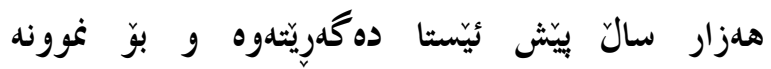

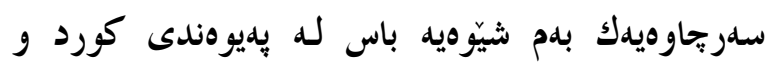

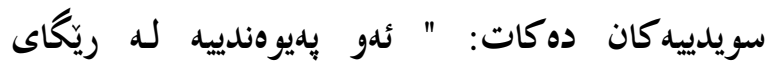

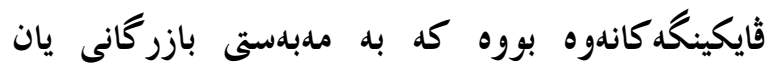

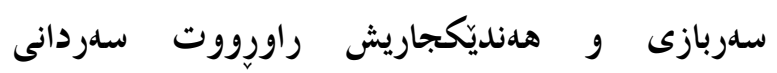

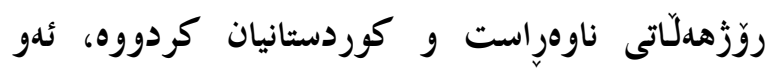

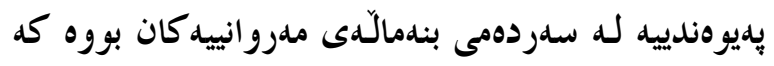

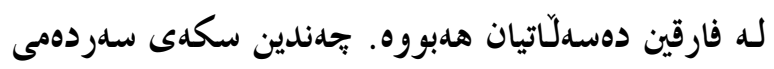

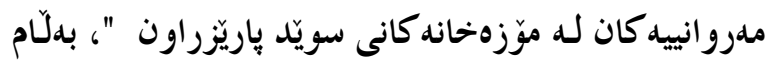

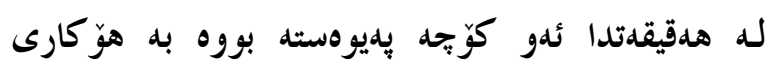

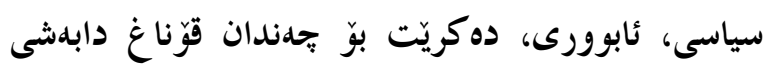
بكدين

سهروتاكانى بزاقى خويّدكارانى كورد:

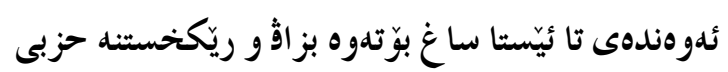
و سياسييه كورد و كوردستانييدكان لله دهستيّكدا له له كوردستانى باكوور به تايبهتيش له شارى ئهستهنبولّ

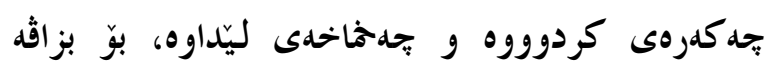

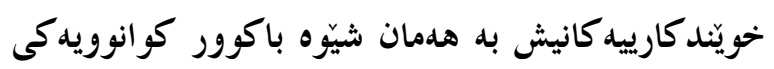

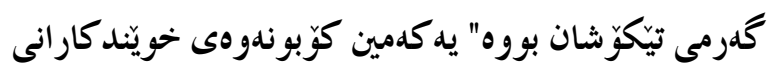

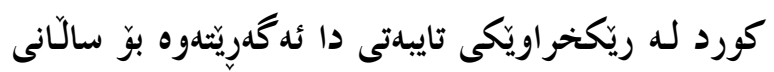

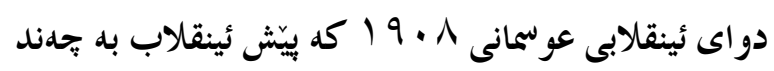

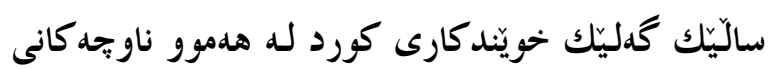

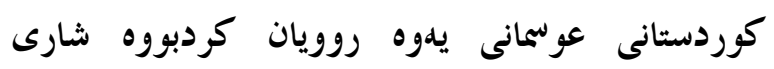

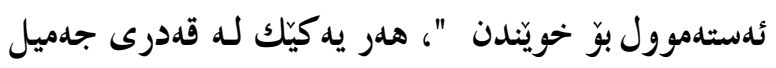

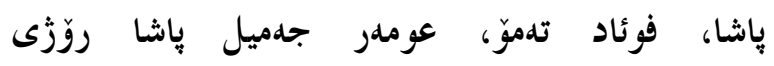
19/ T/V/TV ئهستهنبولَ دامهزراند. سهرهتا خويَندكاره كورده كانى زانكوّ كانى تور كيا به تايبهتيش لـه ئهستهنبولَّ بوونه ئهندام
دهولّدتى عوسمانيدا بكهين، ئهم رووداوه تا ئيّستا كارى

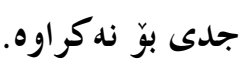

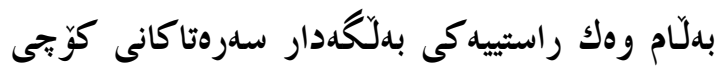
كورد بوّ دهرهوه لـه كوردستانى باكوور لـه تحله كانى سهدهى رابردوو دهست بيّده كات به تايبهتيش تجوونى بوري

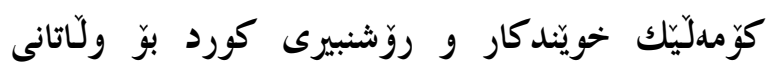

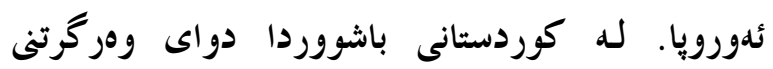

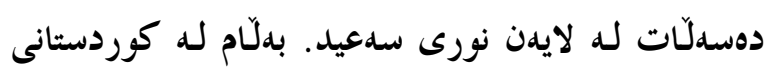

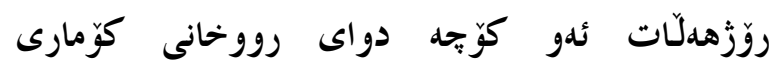

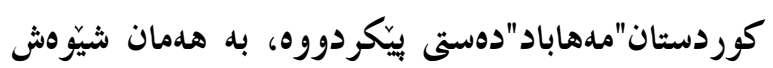

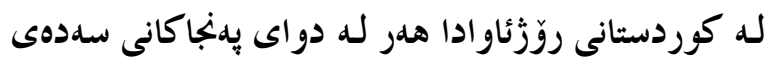
رابردوو جحهندان خويَندكار و روّشنبير روويان له دهرهوه

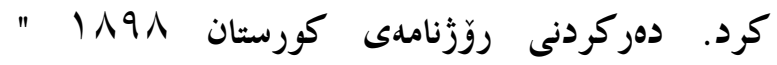

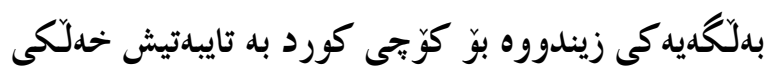

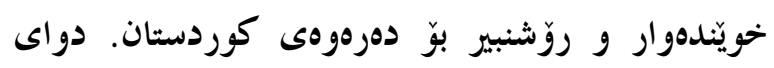

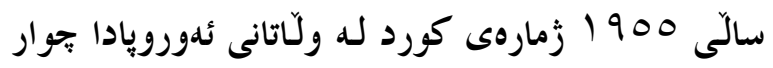
سهد كهس بووه ـ دواى ئدم ميّزووه ئهو زممارهيه بهردهوام

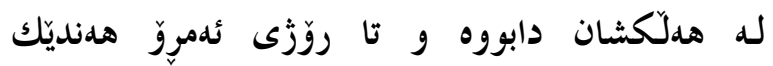
سهر:جاوهى نا رهلسمى زمارهى كورد لـه دهرهوه به تايبهتيش

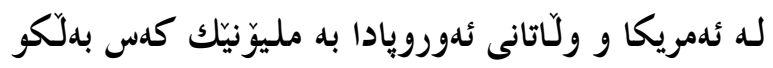
زياتر دهخممليّنن. دابهشكردنى كوردستان بهسهر جورار دهولَّتى جياواز

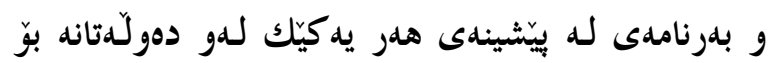

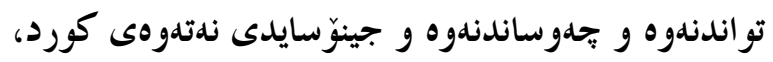

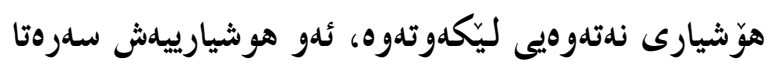

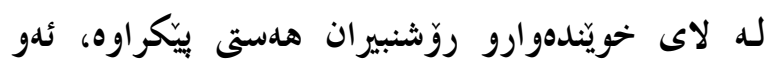
دهستهيدش تا بوّى لواوه و بوارى بوّ رهخساوه ئدو شيّوه

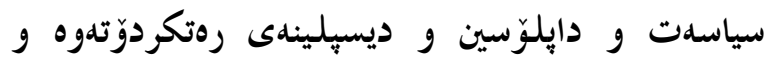
خهباتى له دزى كردووه، بدلّام كه لـه ناوهوه هيج

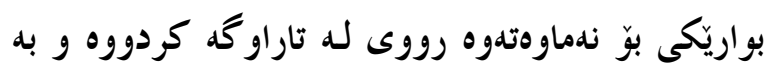

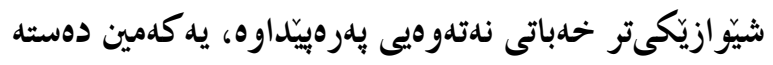

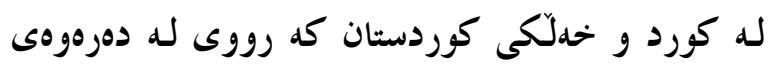


" Students Society In Europe- KSSE

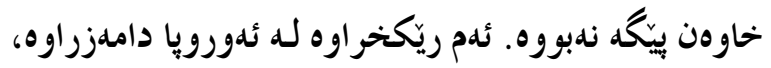

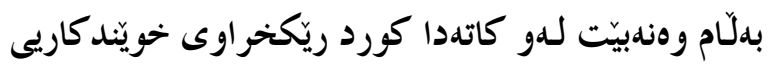

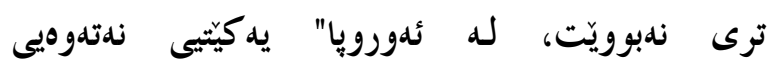

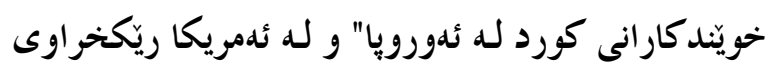

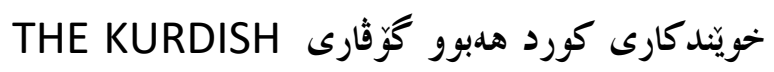
JOURNAL

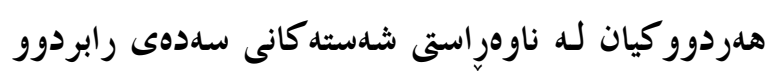

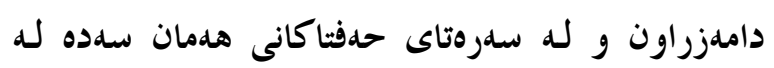
جالاكى كدوتوون.

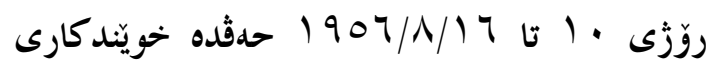

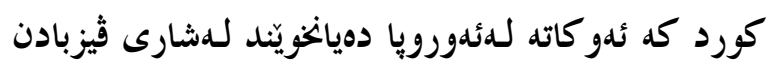

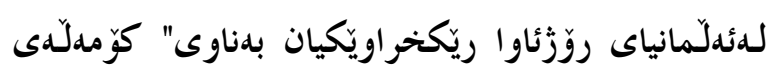

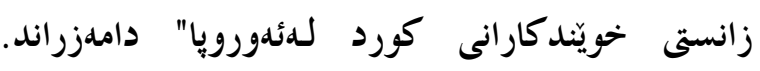

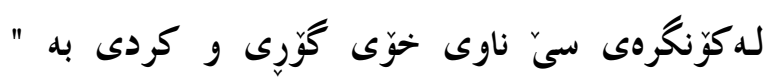

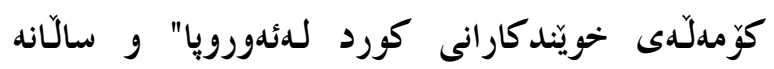

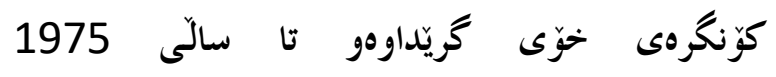

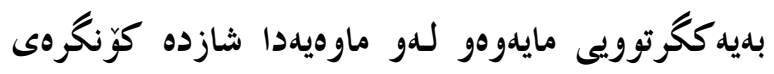

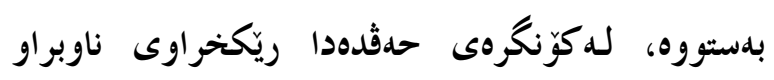

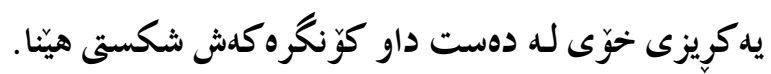

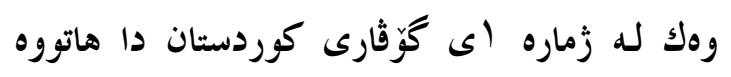

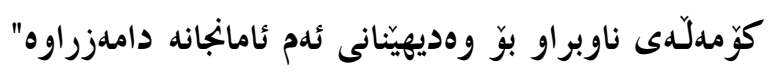

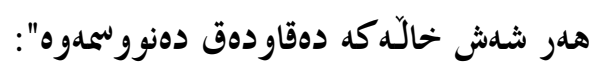

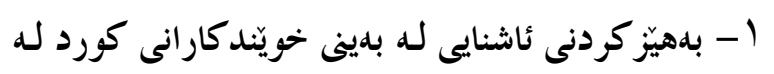

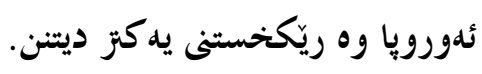
r - هانينهدى يارمدتى دانى مادى له بد بدينى خويّند كارانى

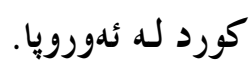
r- مشووردان و بلدرزكردنهوهى زانستى نيشتمانى كورد.

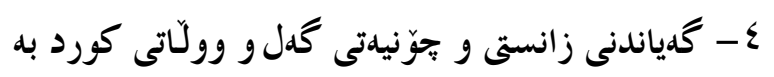
جيهان.
لدو ريّكخراوهدا، بدلّام بِاشان دديان كهسايدتى نيشتمانيى

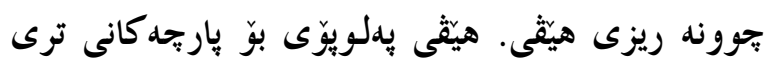

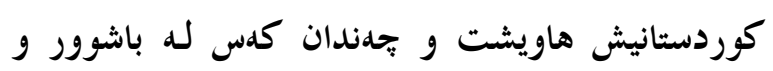

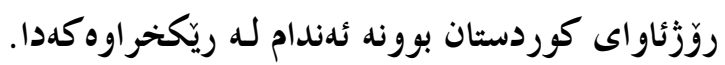

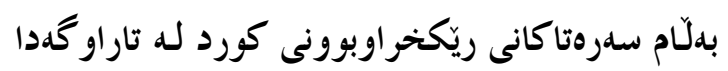

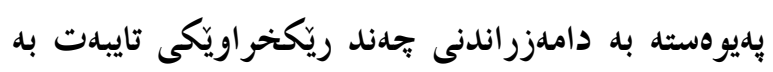
لاوان و خويّندكارانى كورد له ددرهوهدا سالّى 1949

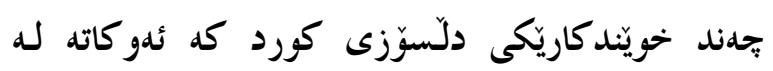

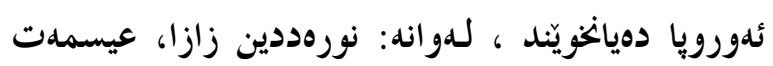

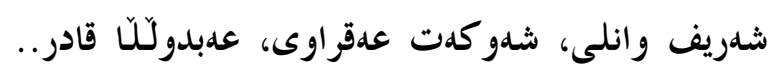

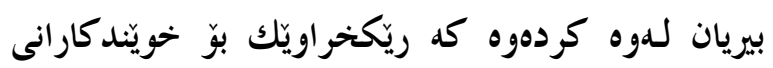

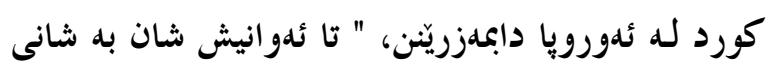

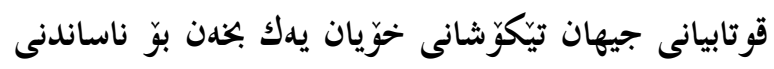

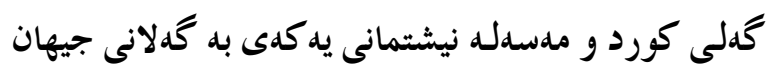

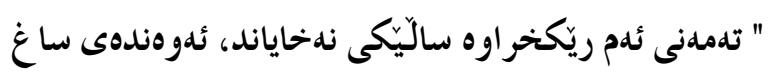

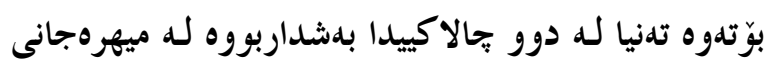

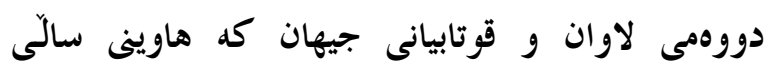

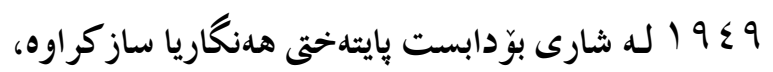

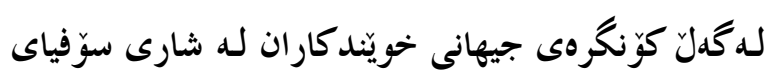

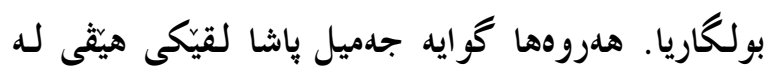

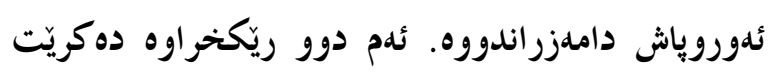

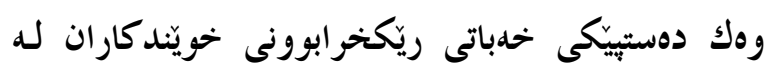

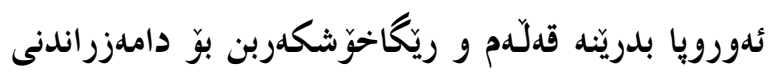

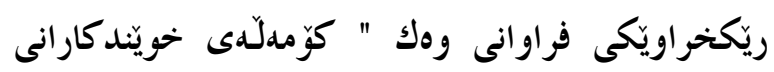
كورد لـه ئهورويا". ميّزورجكهى كَّمدلّى خويَّدكارانى كورد:

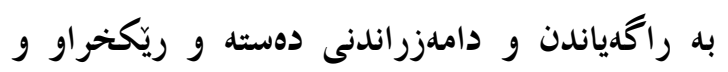

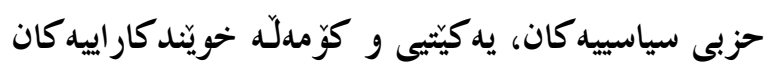

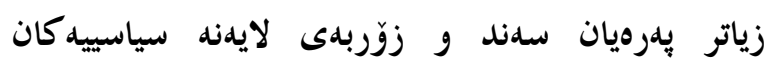

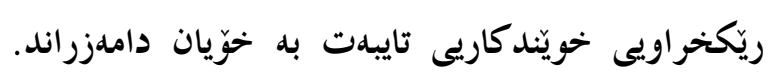

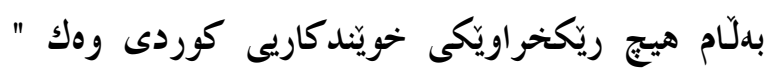

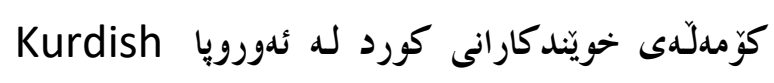


خويَندرانهوه كه لـهلايدن جِهندان كهسايدتى و حزبه كورد و كوردستانييه كان بوّ كوّنگره ناردرابوو.

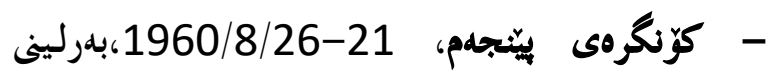

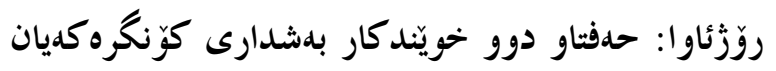

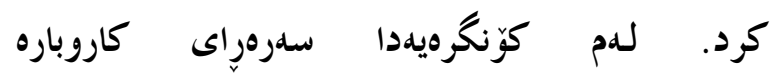
ريّكخر اوهييد كان و خويّندنهوهى وتارى سهروّكى كوّمهلّه

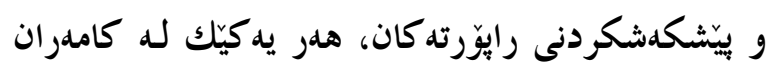

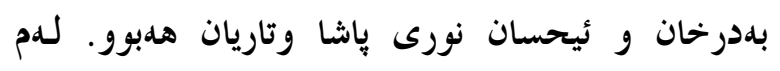

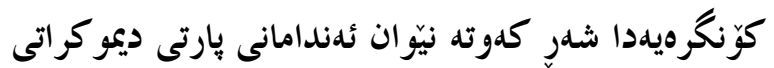
كوردستان- عيراق و حزبى شيوعى عيراقى.

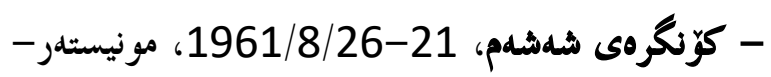

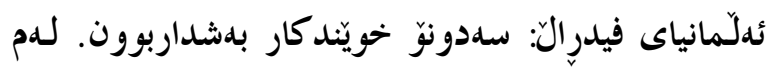

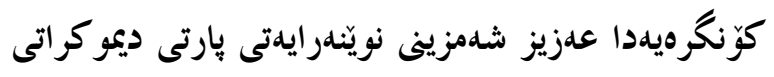

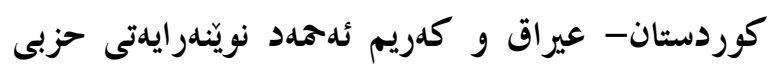
شيوعى عيراقى دهكرد. ديسان لـهم كوّنكرهيه كيّشه

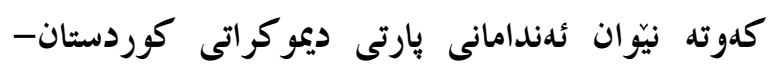

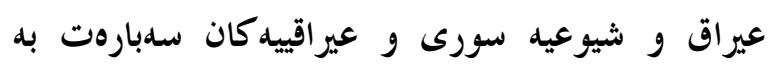

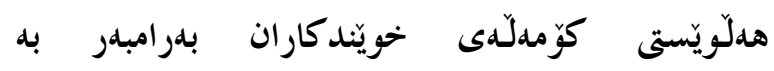
دهسلَّاتدارانى عيراق و سوريا.

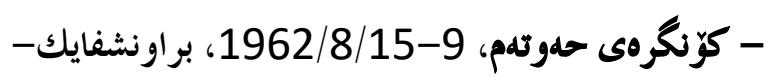

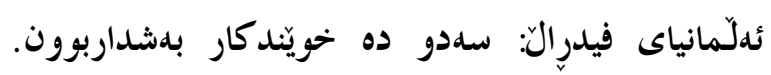

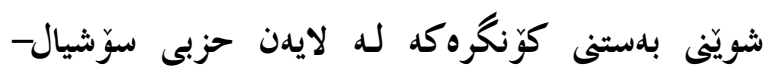
ديمو كراتى نهمسا دابينكر ابوو.

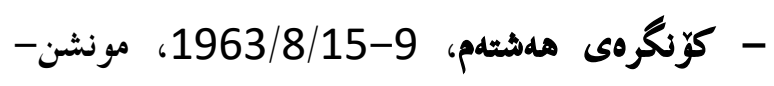

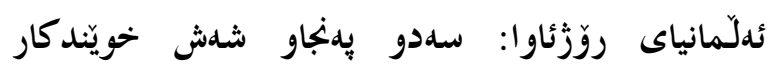

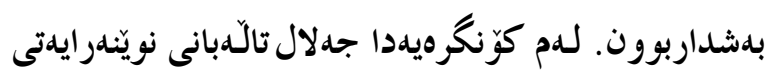
شوّرشى كوردستانى باشوورى دهرده. للهم كوّنكرهيلدا

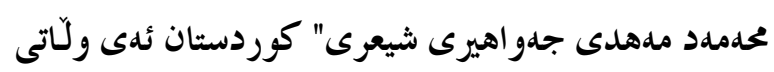
قارهمانان"ى خويَندهوه.

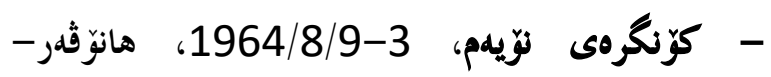

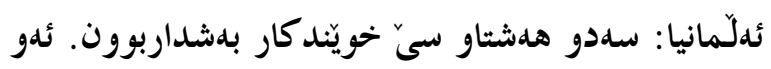

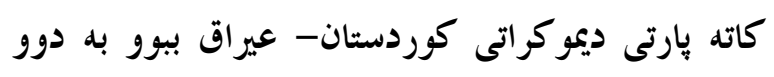

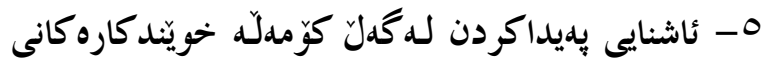

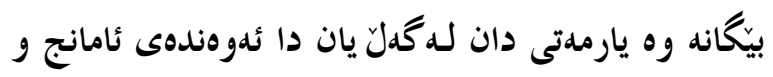

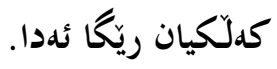

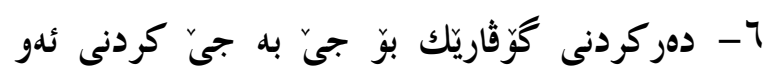
ئامانجانه " كُنجينهى كوّمدلّدى خويَندكارانى كورد لـه ئدوروبيا

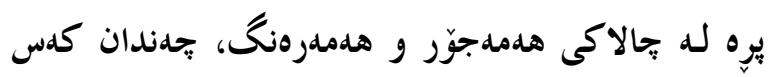

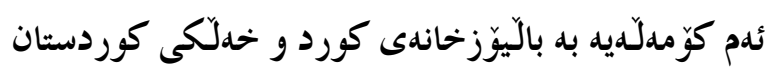

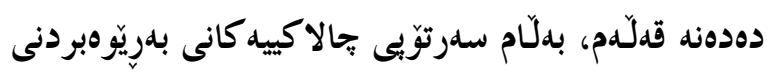
كوّنكُرهى سالَانهى كوّمدلّه كه بووه.

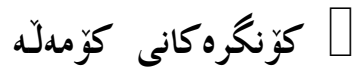

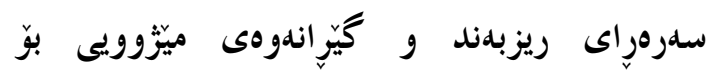

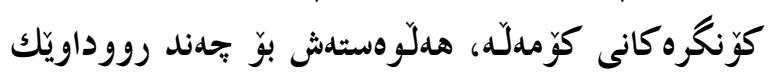

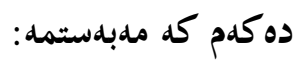

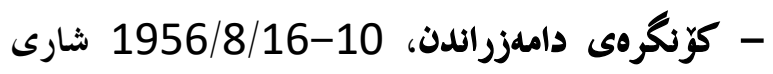

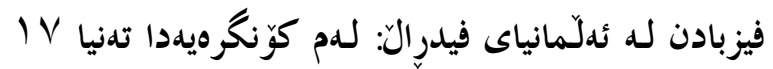

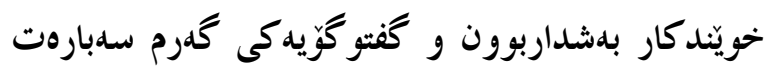

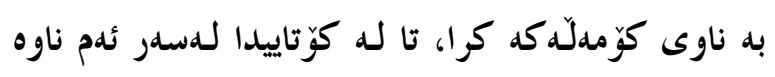

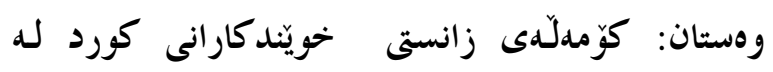
ئندورويا.

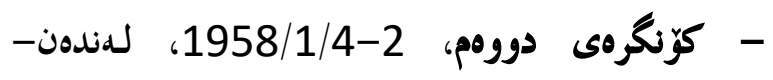

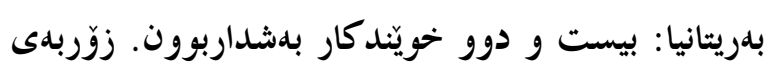

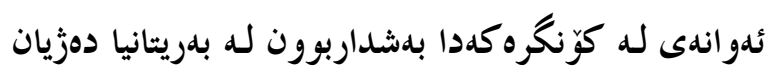
تمنيا دوو كهسيان نهبيّت.

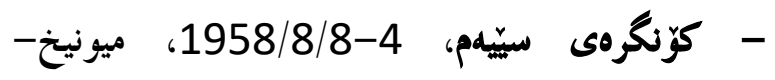

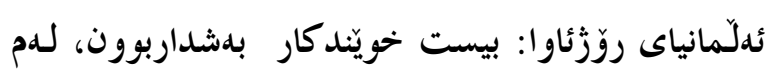

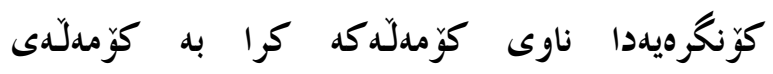

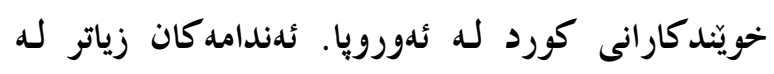

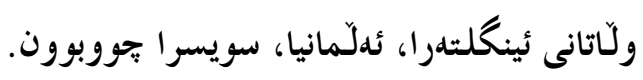

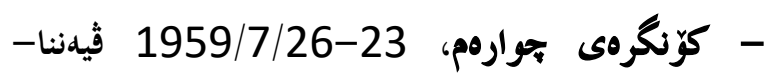

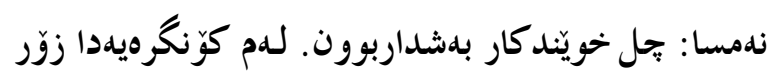

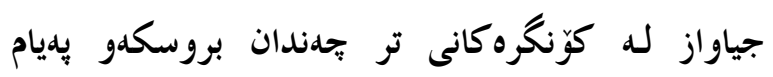


له كوّنكره كهدا بوّ دهستهى سكرتاريدت سيّ كهس

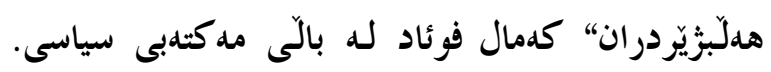

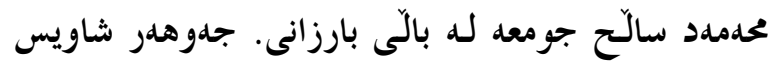

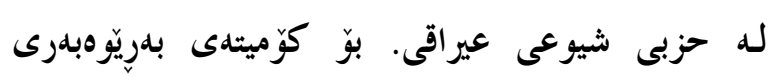

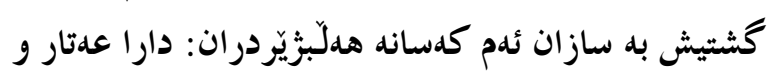

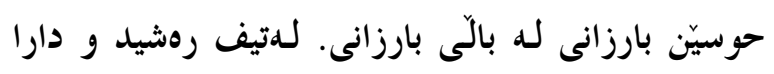

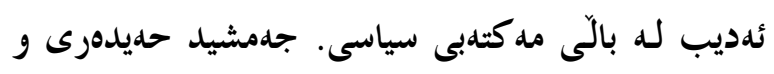

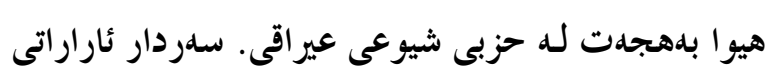
بيّلايهن.

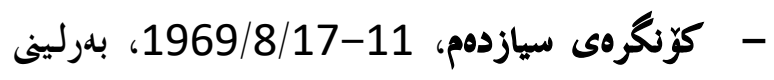

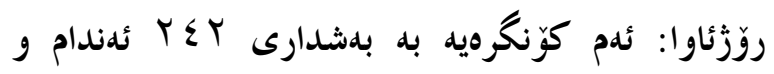

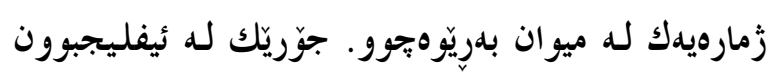

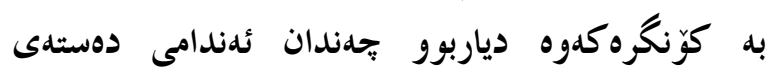

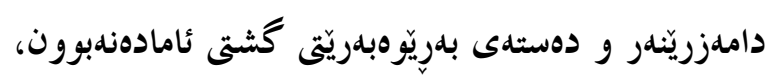
ياخود خحوّيان كانديد نه كرد.

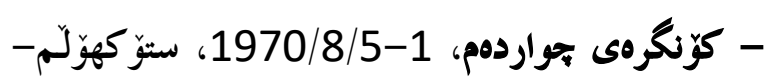

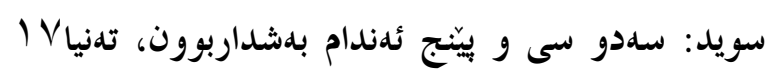

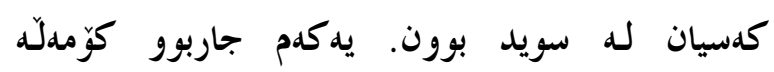

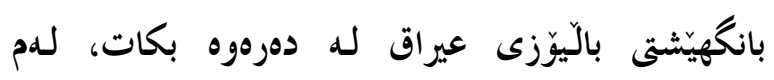

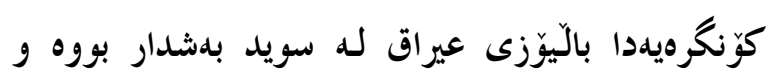

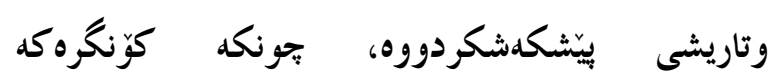

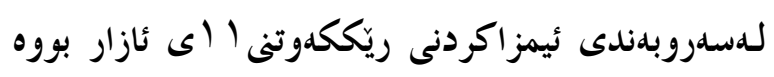

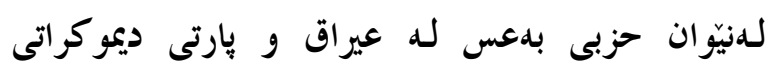
كوردستان- عيراق

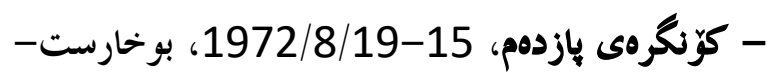

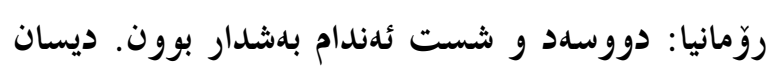
حكومدتى عيراقى فشارى خسبووهسهر حكومهتى نهمسا

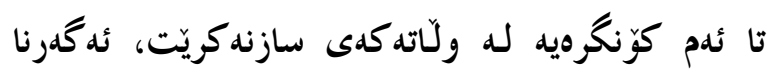

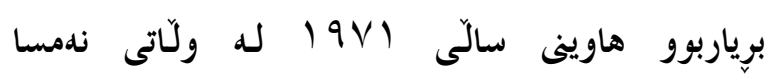
سازبكريَت. ئهوهى سليره دواى ئهوهى روّمانيا ريّكا

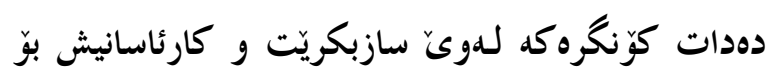

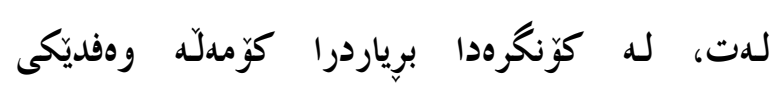

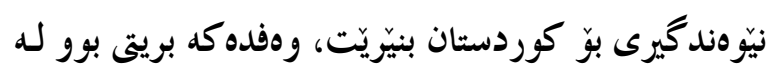
عيسمدت شهريف وانلى و كهمال فوئاد.

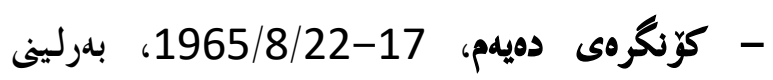

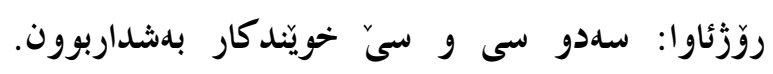

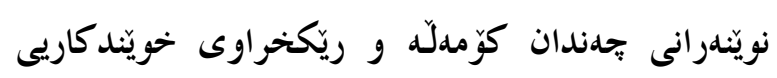

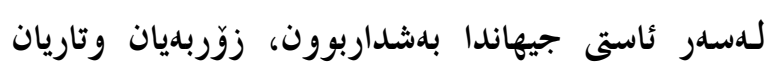

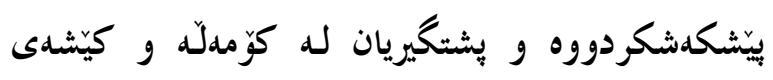
خدلّكى كوردستان كردووه.

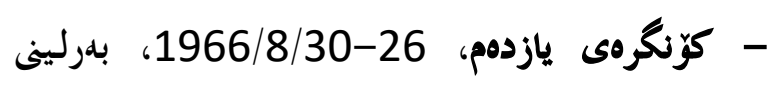

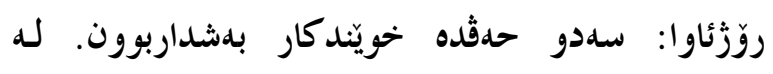

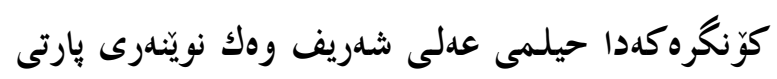
ديمو كر اتى كوردستان- بالّى مد كتهبى سياسى و ئيسماعيل

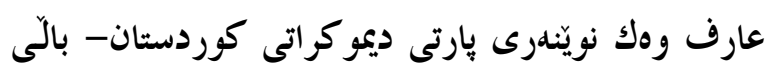

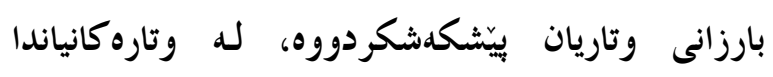

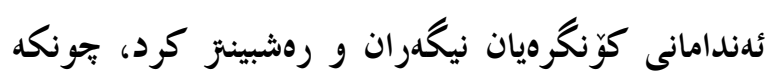

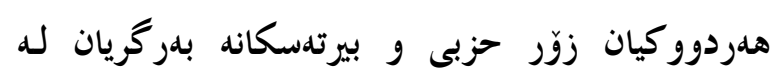
يارته كانى خوّيان ده كرد

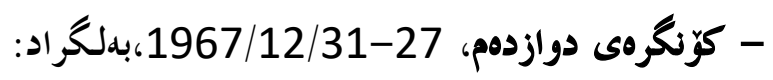

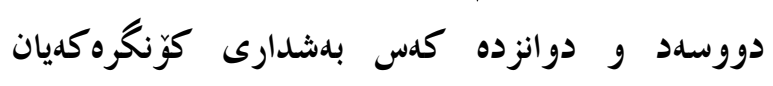

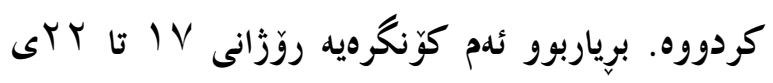

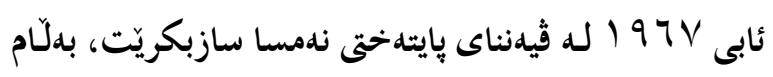
نويْنهرى وهزارهتى دهرهوهى نهمسا هدفتلهيهك يِّش ئهو

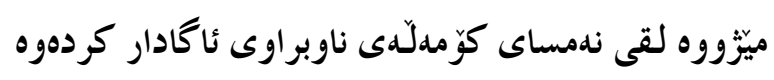

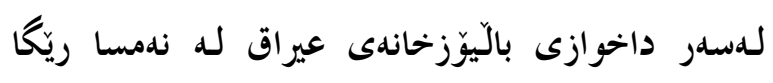

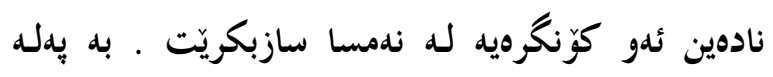

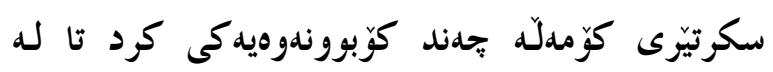

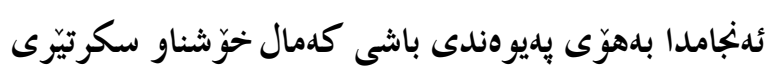

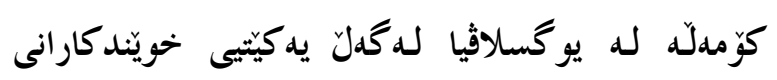

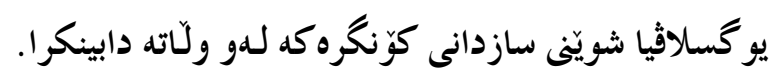

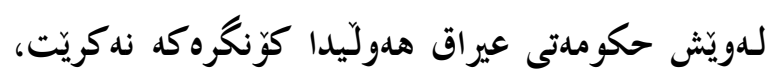

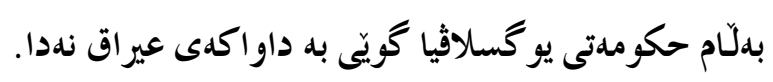




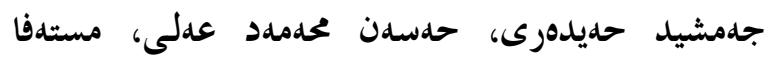

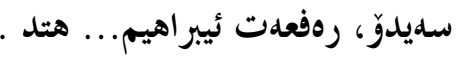

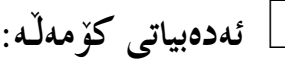

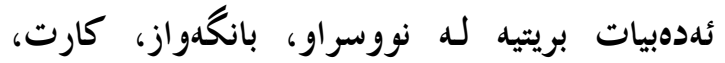

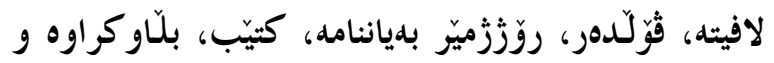

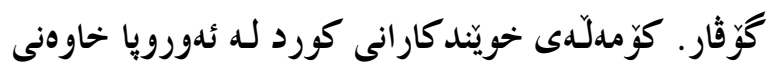

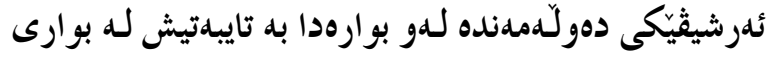

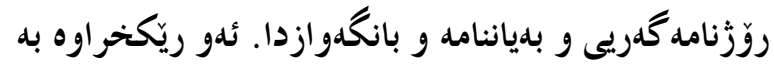

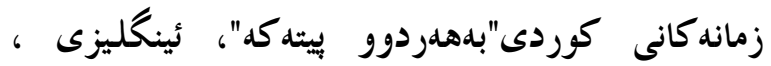

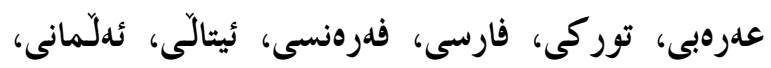

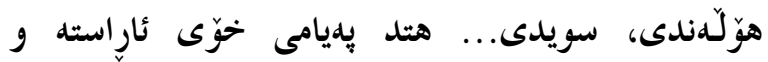

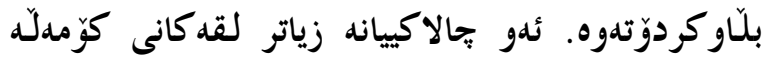

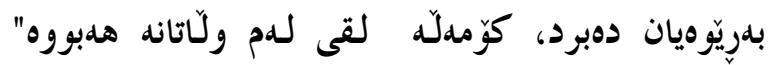
ئينگُستان، فهرنسا، سويسرا، نهمسا، ئيتالّيا، ئهلّمانياى

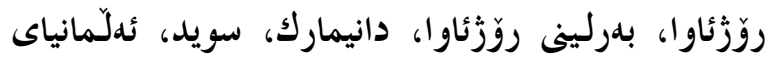

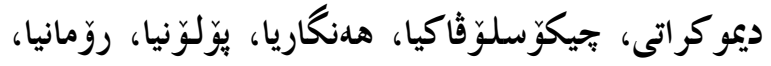

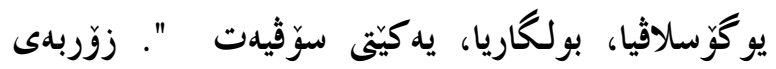

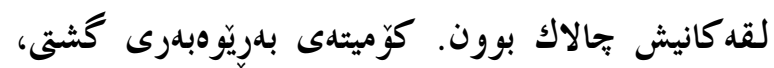

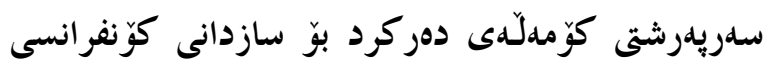

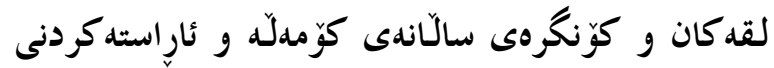
ريّنمايى بوّ لقده كان. ئهو ئهدهبياتانهى كوّمدلّه به بِهدندان شيّوه و شيّواز

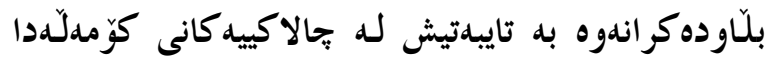

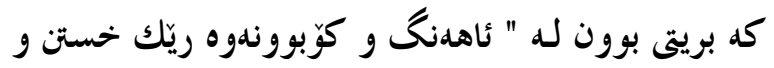

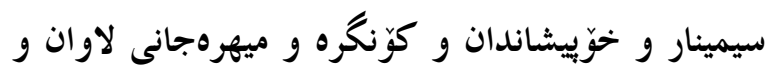

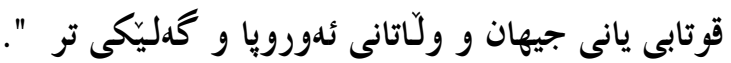

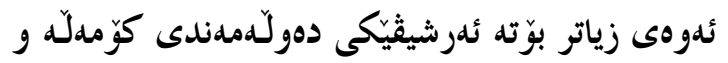

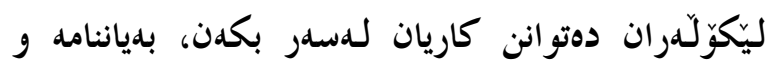

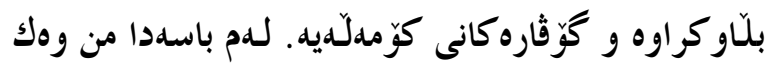

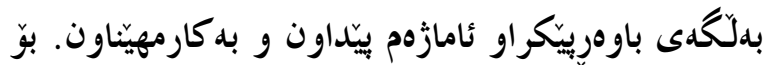

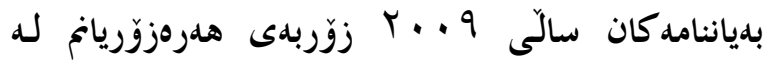

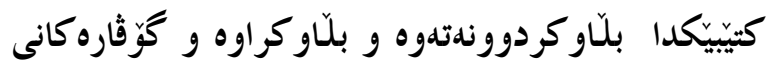

ئهوانه دهكات كه للهدهرهوهى روّمانيا ديّن، نويَنهرى حزبى بلهسى علرهبى ئيشتزاكى عير اقيش بلشداربووه .

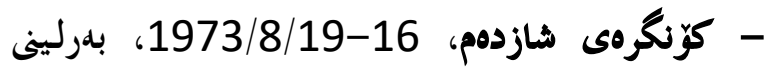

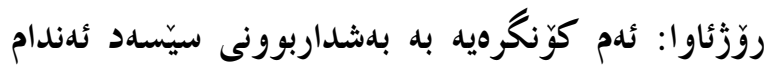

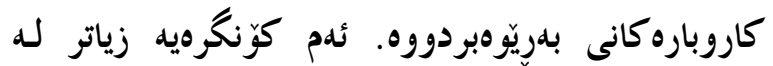

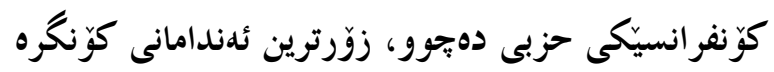
ئهندامى يدك حزب بوون و دهيان ئهندامى يِّشورى

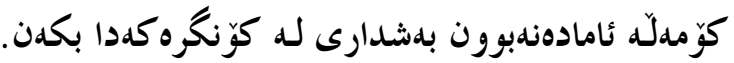

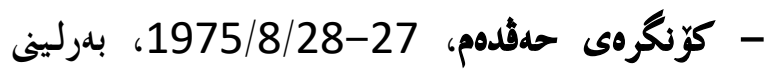

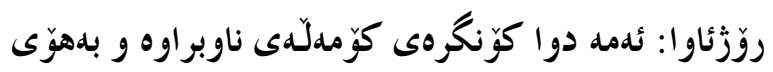

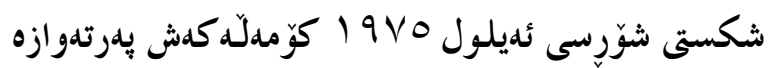

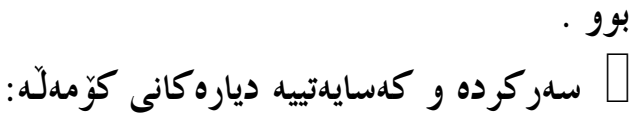
زوّربهى هدرهزوّرى ئهوانهى سهركردهو ئلندامى كوّمهلّدى خويَندكارانى كورد بوون به مهبلهتى خويَندن

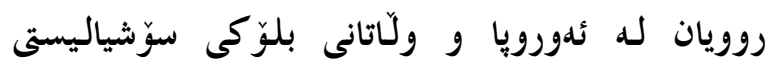

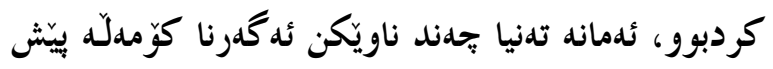

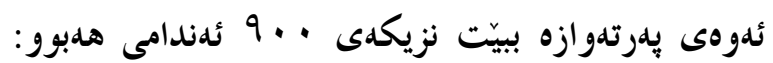
ئهحهد زهمجيى، ئهمدد رهسوولّ بهديع قوتب، تهحسين

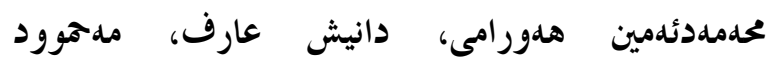

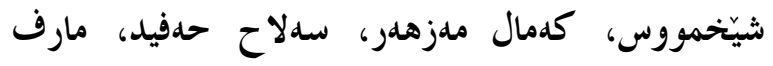
خهزنهدار، كهمال محهمهد سهعيد، دارا رهشيد، كاوس قدفتان، خحاليد خحالّ حهسلن زولفهقار، دارا توّفيق، سهعدى ئدمين دزهيى، تاهير خهفاف، زاهير حوسيّن، عيسمدت شهريف وانلى، عومهر رهمزى، فوئاد سالّح رهشه، مهحموود كانهبى، مستهفا قازى، نورهدين زازا، يوسف ئهديب، ئيحسان فوئاد، عومهر دزهيى، ئيبراهيم دزهيى، ئهرجومهند سديق، عومهر شيّخمووس، عيزهددين مستهفا رهوولّ نازدار رهشيد جهودهت. زاهير مللا

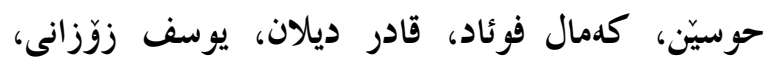
سلّاح سهعدولّلحه، نهجيب خحفاف، نهجمددين كايا، 
دهستگيركردن و زيندانيكردن بهرامبهر به كورد و و

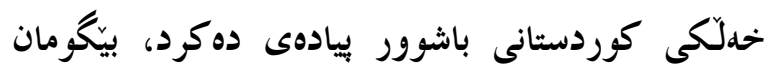

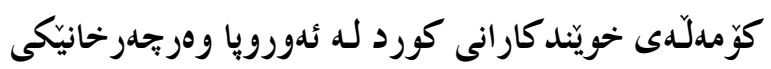

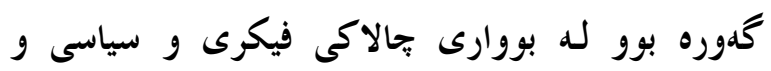

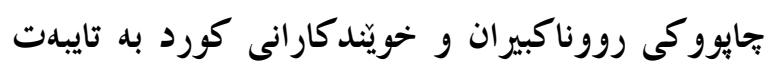

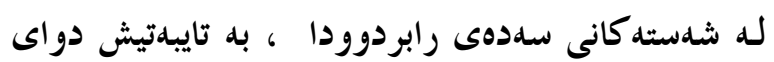

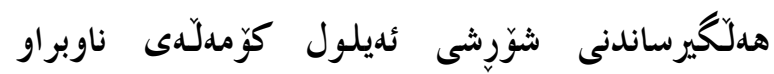

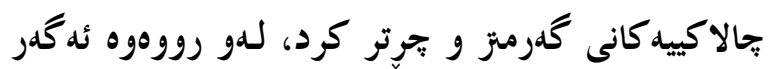

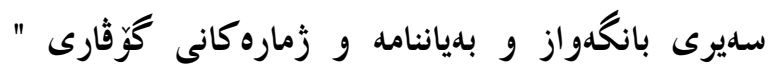

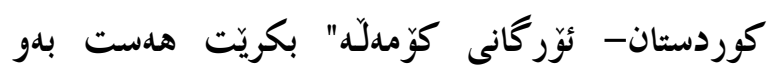

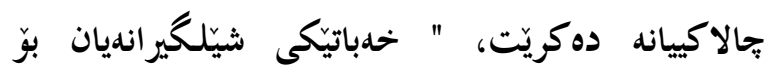
ناساندنى كيّشهى كورد لـه دهرهوه " دهست بيّيكرد.

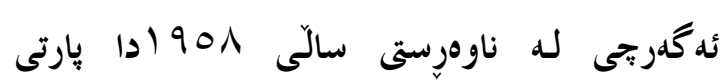

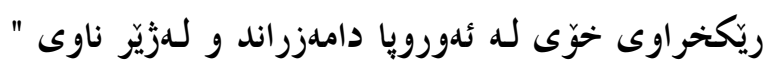

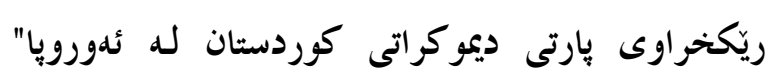

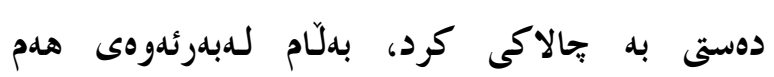

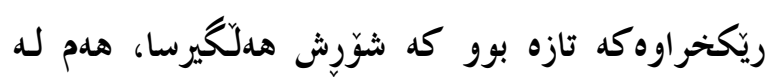

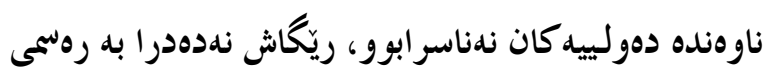

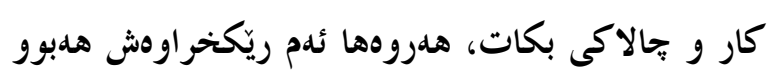

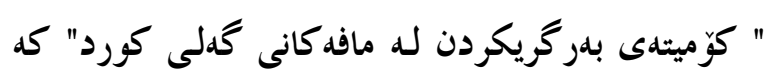

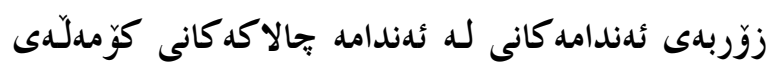

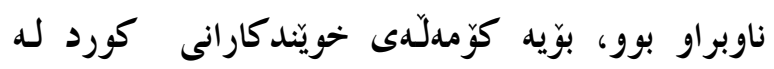

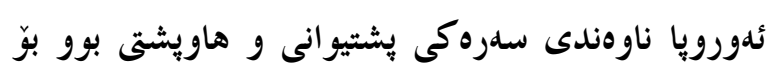

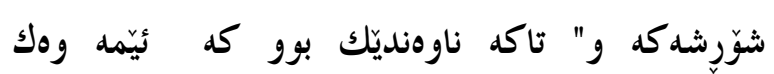

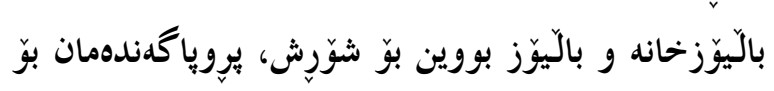

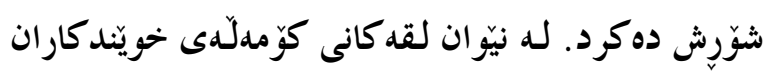

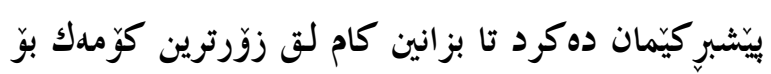

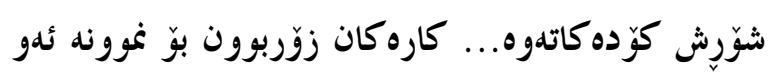
ياداشتنامانهى بارتى كه به دهستمان ده گمديشتن بوّ سهر

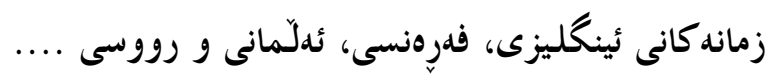

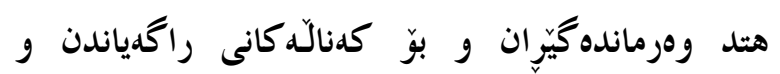

ئهمانهن: كوردستان ، HEVIYA WELET، ، يِشنگ،

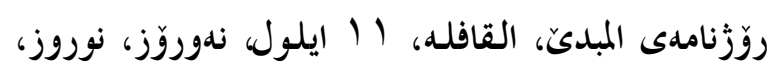
DENGE ،Die Kurdische Revolution

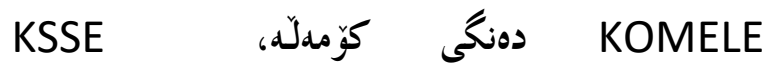
INFORMATION Kurdish news يشتيوانى كوّملَّلى خويَّدكارانى كورد له شوّرِّى تهيلول: ئه گَربحى لـه كوّبوونهوه كانى دهستيِّكى دامهزراندنى

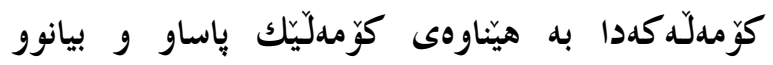

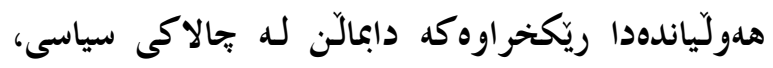

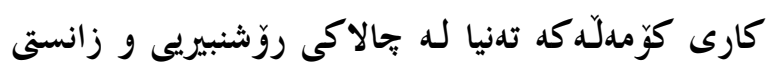
سنووردار دهرد، هدربوّيه ناوى كُومدلّدكهشيان ناونا

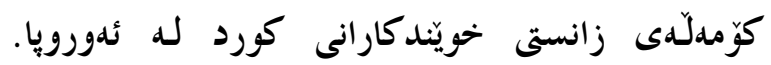

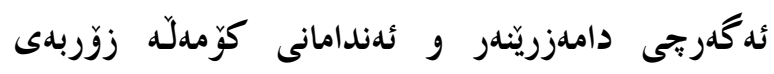
هدرهزوريان له دهستهى بِيّشهوهى نيشتمانيهروهرى و و

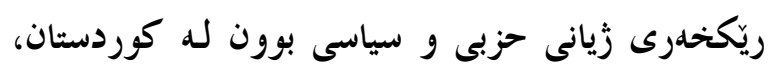

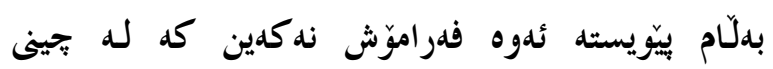

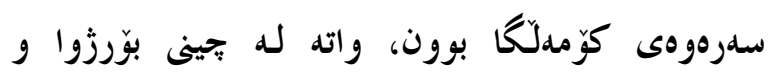

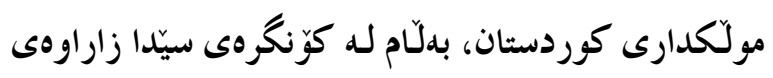

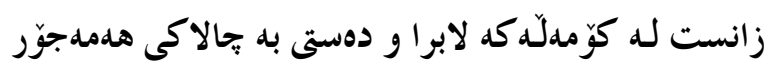

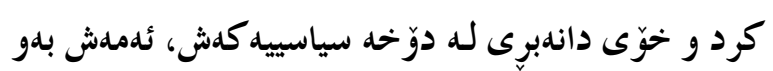

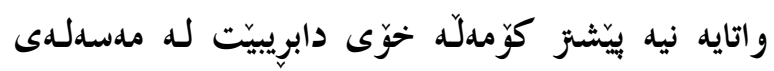

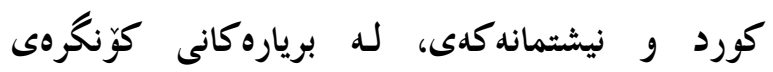

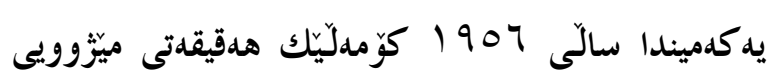

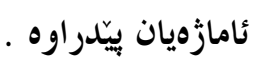
بوونى ريّكخر اويّكى للهو شيّوهيه و بورنى كوّمهليّكَك

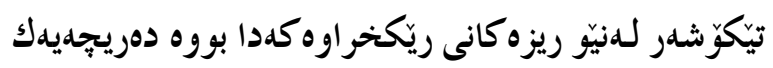
بوّ باشتزناساندنى كيّشهى كورد به ناوهنده كانى بريار لـه له

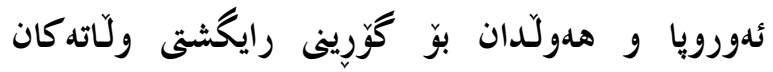
بلهرامبهر به كيّشه كه، به تايبهتيش دواى هدلّكيرساندنى

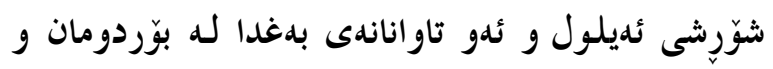




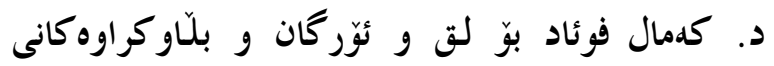

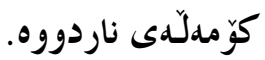

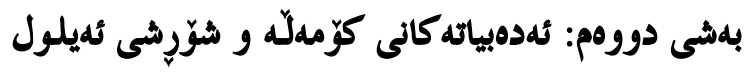
لمسمروتادا:

ئهر كىى هدر كاريّكى ميّديايى كَدياندنى رووداوه، شيّوه

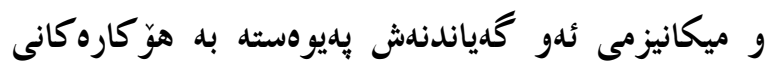

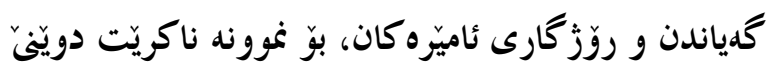

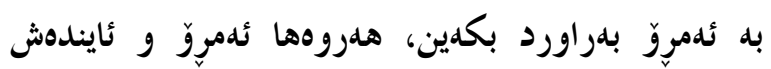

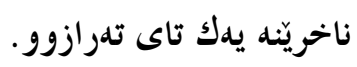

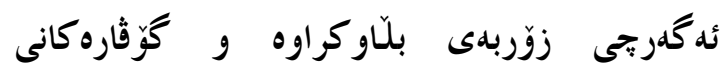

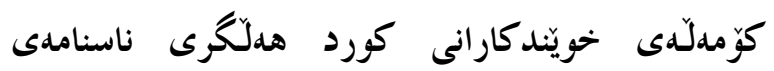

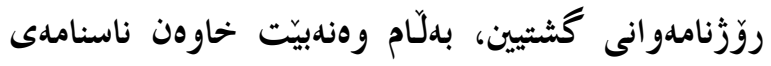
تايبهت به خوَّيان نهبيّت، بله تايبهتيش ئلهوانهى بله

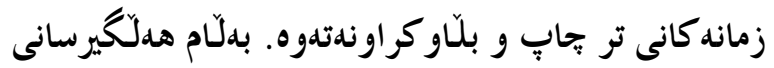

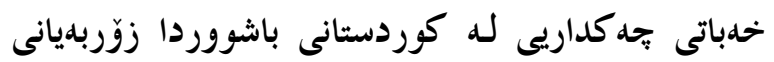

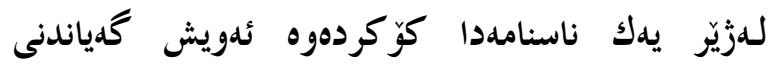

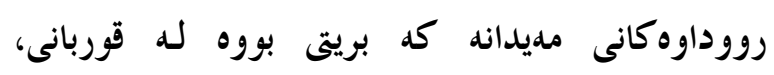

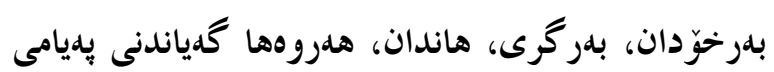
شوَرِّ و ماففى رهواى نهتهوه كممان.

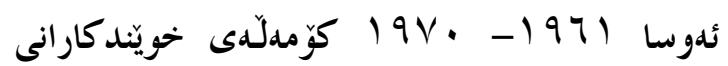
كورد لـه ئدورويا تدواوى هوَ كاره كانى گَدياندنى خوّى

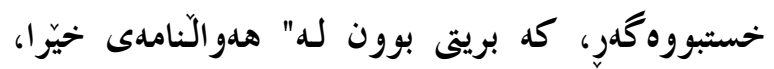

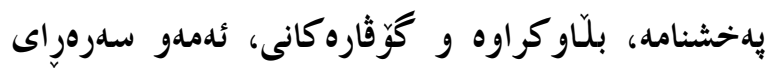

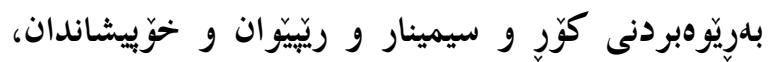

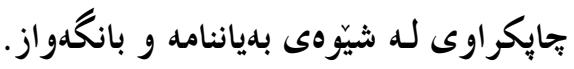

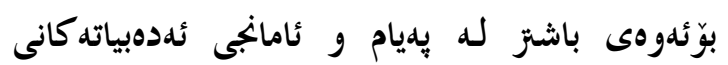

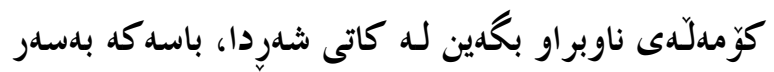
ئهم ناونيشانانهدا دابهشى ده كهم:

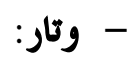

وتار ووك هدر كاريّكى نووسين يديوهسته به هونهركارى، ئهوهى وتارى روّزنامهنووسى لـه وتارى

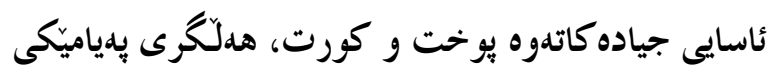

سهنتهرهكانى بريارى ولّاتان و حزب و ريّكخراوه

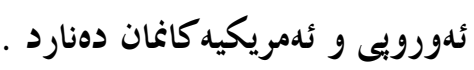

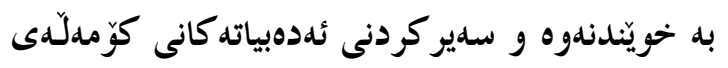

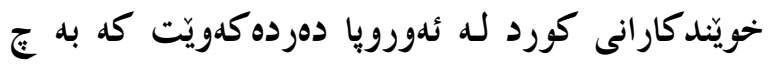

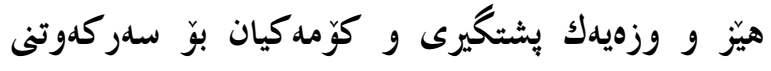

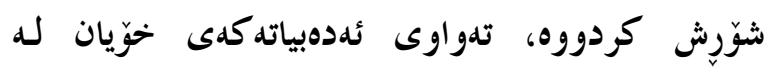

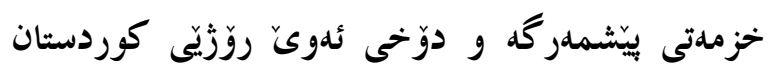

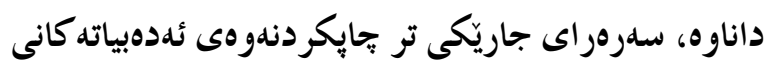

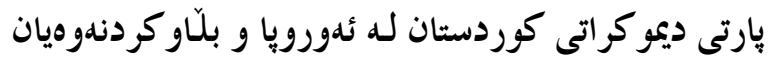

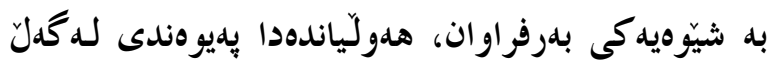

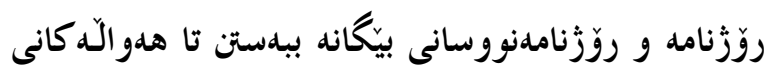

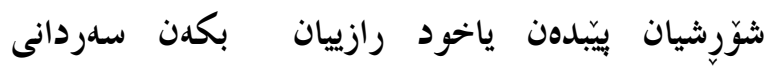
كوردستان بكمن بد مهبdستى گو استنهوهى رووداوه كان، سهرهراى بِيليوهنديكردن به كهسايدتى و ناوهنده كانى بريار

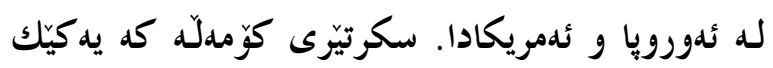

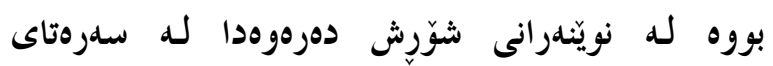

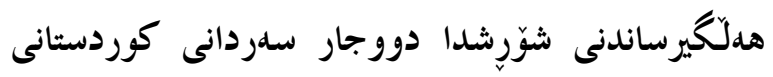

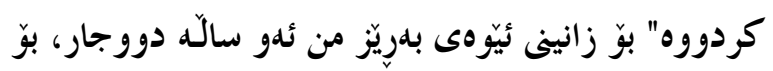

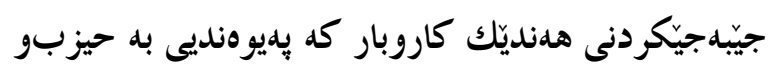

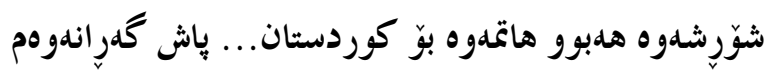

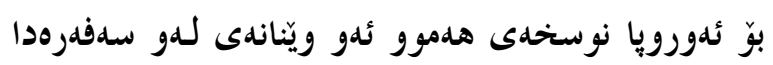

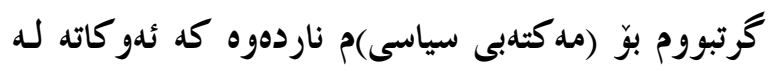

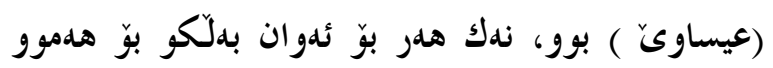

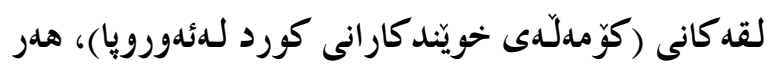

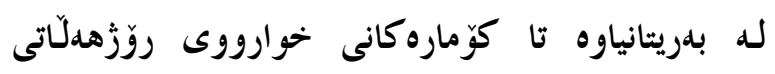

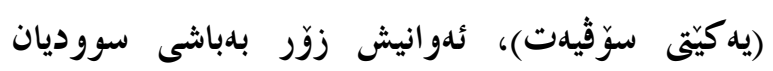

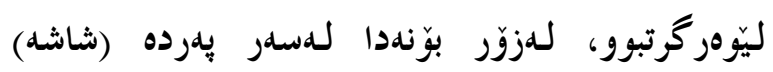

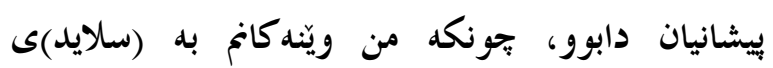

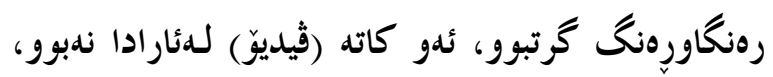
(سلايد) باوبوو ". ئه گهر سهيرى ئهدهبياته كانى كوّمدلّده

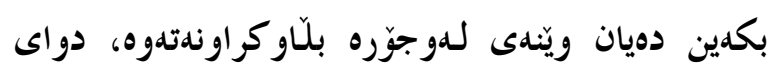
سوّر اغكردن بوّم دهر كهوت زوّربهى ويّنه كان كاتى خوّى 
دوايدا يِّشكهش هلمور كورديّكى دلّسِّزى ئه كدين له

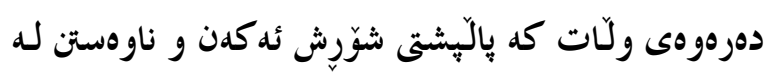

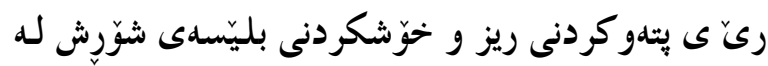

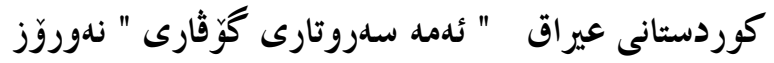

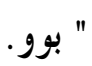

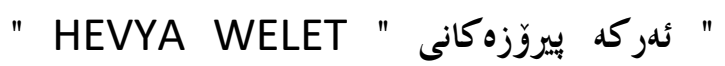

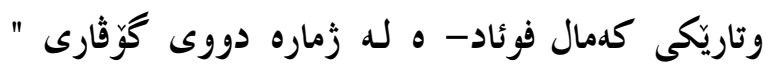

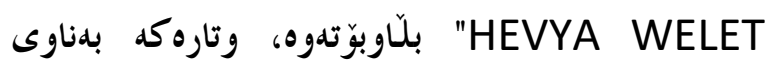

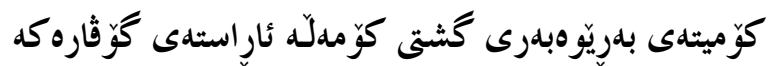

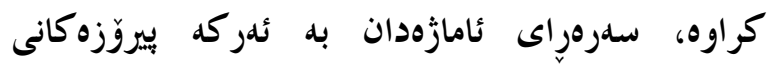

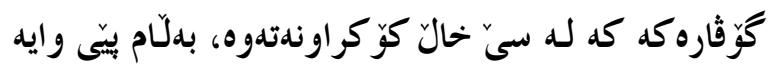

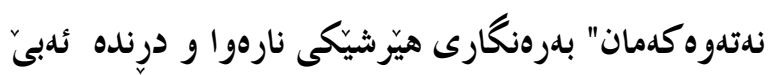

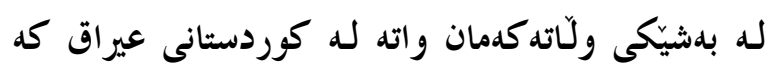

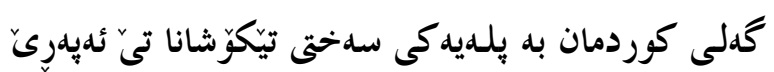

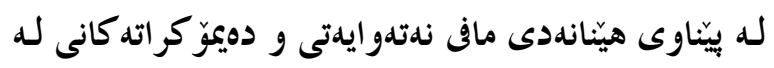

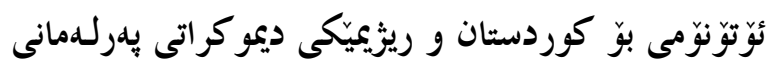

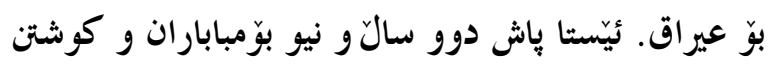

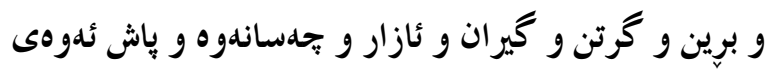

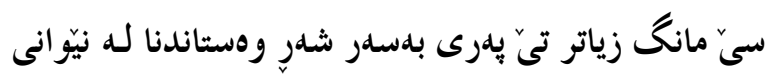

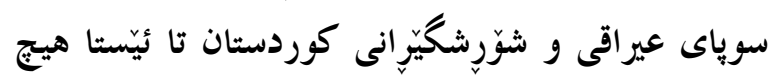

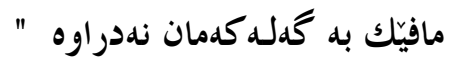

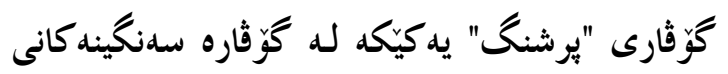

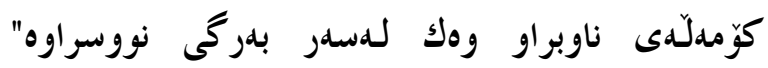

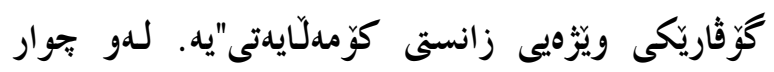

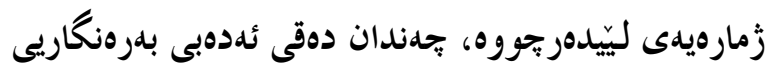
نووسهره ديار و ناسراوهكانى كوردى بلّاو كردوّتهوه.

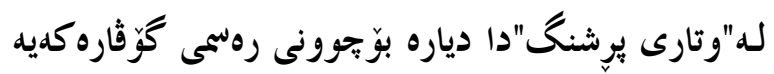
و ئيمز اى دهستهى نووسهرانى للهسهر داندراوه خوّيان به

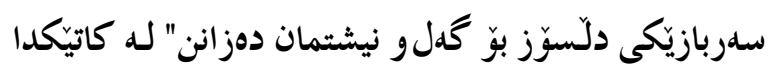

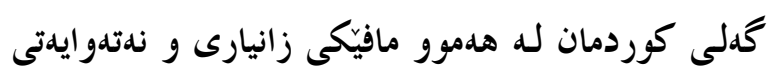

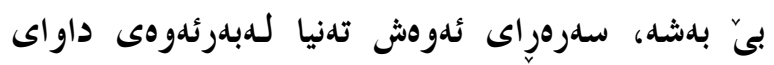

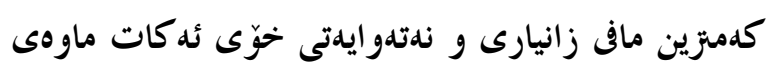

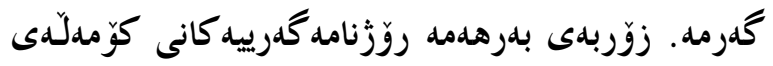

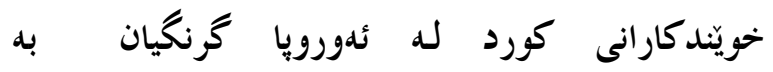

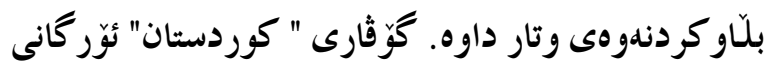

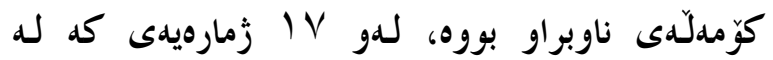

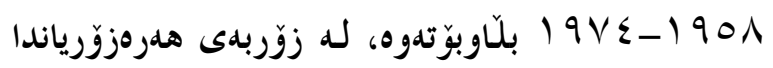

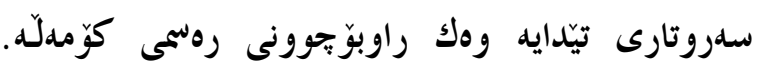

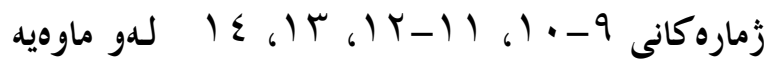

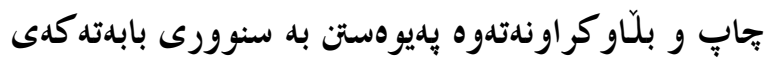

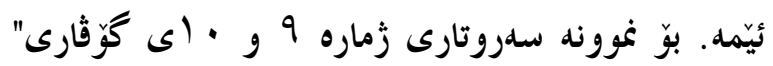

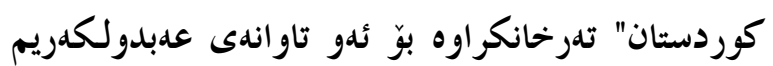
قاسم دهرهدق به خحلّكى سفيل لـه كوردستانى باشووردا

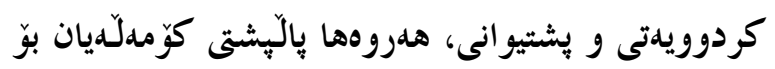
شَّرشى ئديلول دووياتكردوّتهوه.

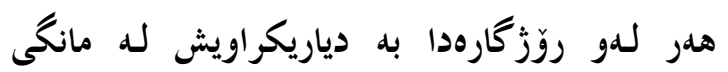

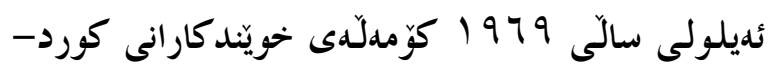

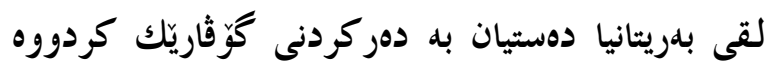

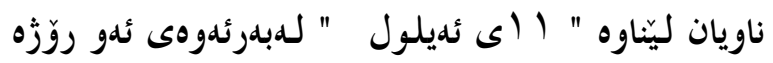

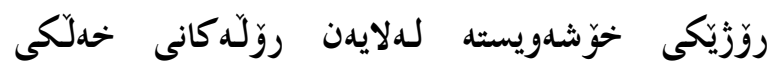

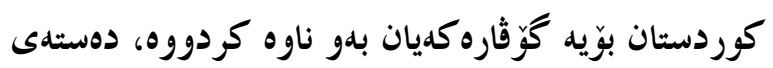
نووسهران لـه سهروتاره كدياندا

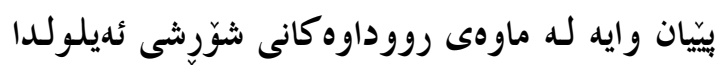

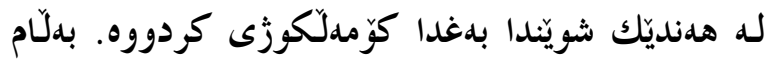

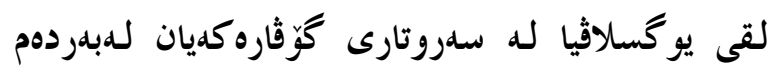
قارهمانيتى شههيده كان دهوهستن كه خحاكى كوردستانيان به خويّنى بياكيان ئاوداوه

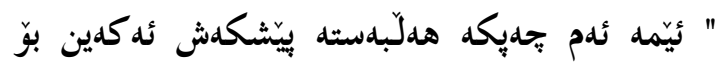

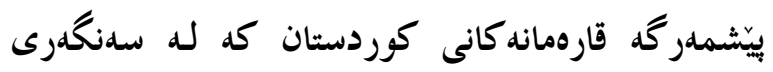

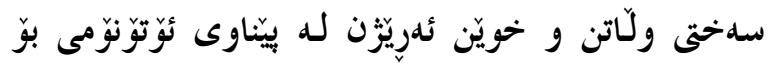

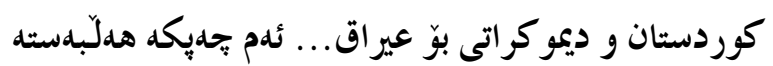

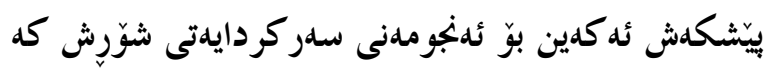

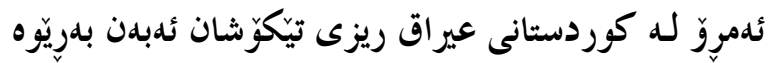

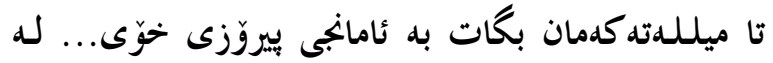


رووى دا، للهم شهرانهدا هيّزهانى حكومهت گُمليّك

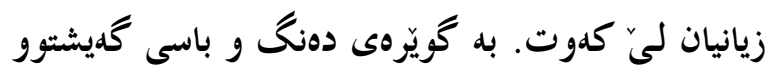

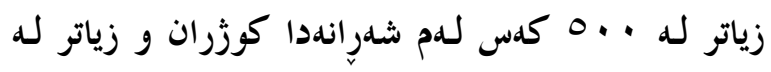
1 1 لـه هيّز كانى ميرى بريندار كراون.

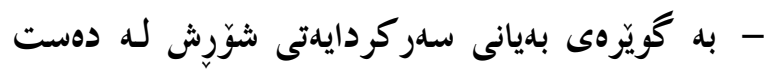

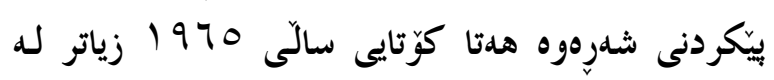

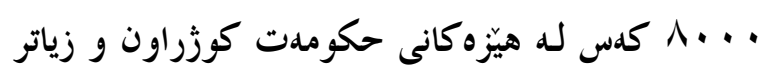

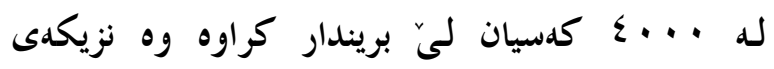

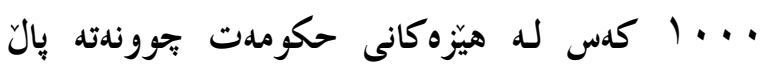

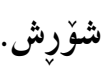
لدهو زَمارانهى كُوّارى " كوردستان" كه لـهماوهى

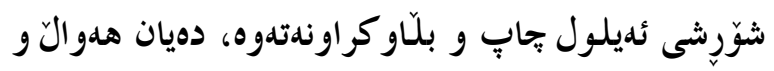

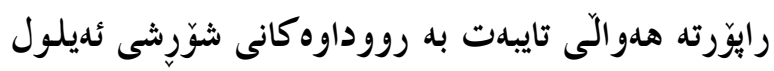

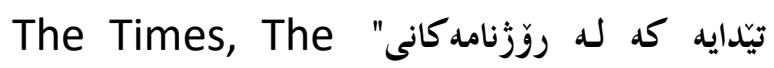
Observer, Daily Teiegraph, The Sunday "... times, The Guardian, Le Monde وهرگيراون و جاريكىى تر بلّاوكراونهتهوه، هدروهها لـه

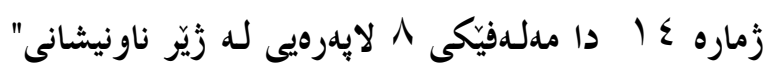
Kurdistan and the press

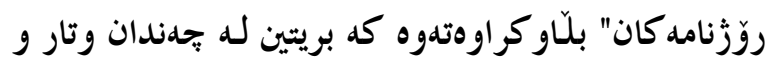
رايوّرته هدو الّى يَليوهست به هdمان رووداو.

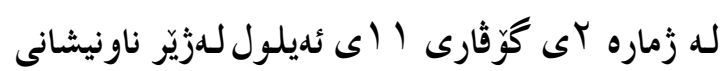

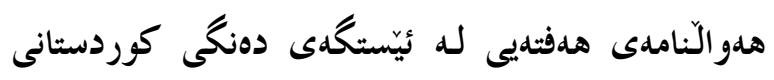

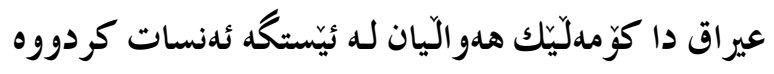

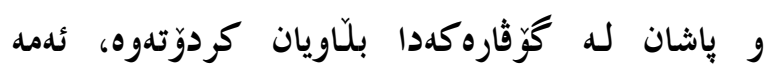

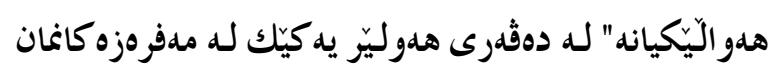
روزّى דبى تشرينى دووهم لله دهوروبهرى هدوليّر هيّرشى كرده سهر كاروانيّكى يوّليس كه يِّكهاتبوون لـه له

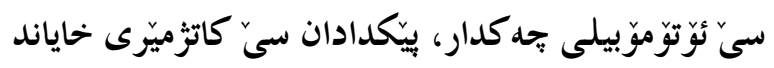

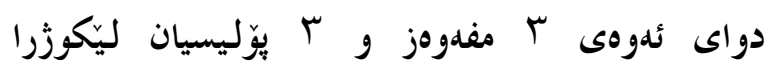

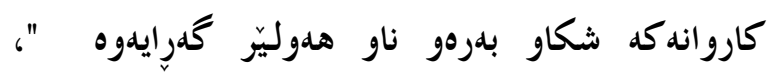

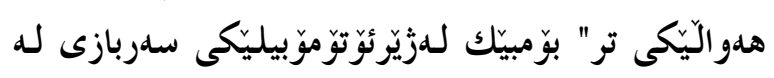

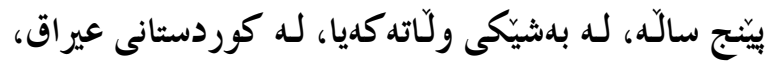

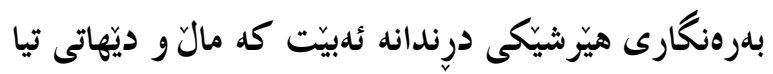

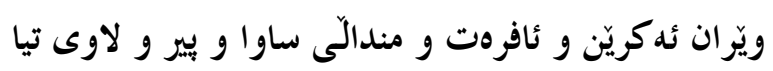

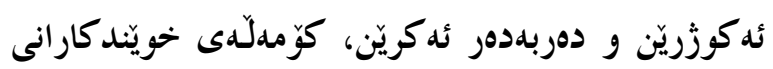

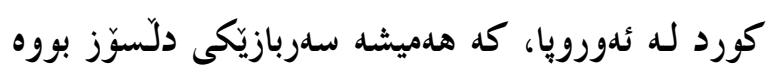

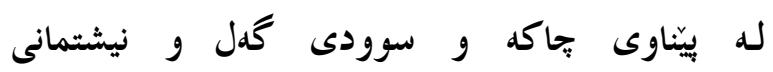

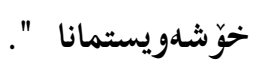

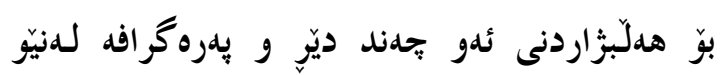

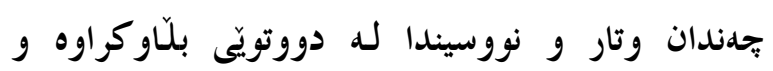

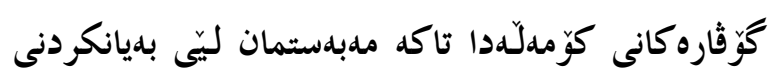

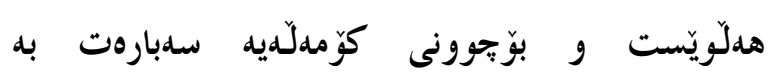

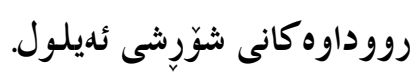
-

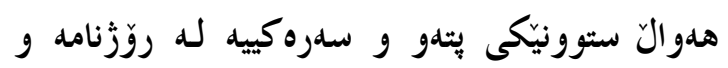

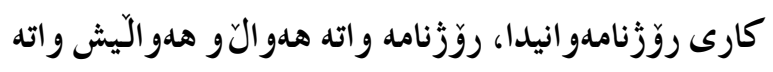
رووبهرى فراوانى روّزنامه. ئهُّهر تهواوى هونهره كانى

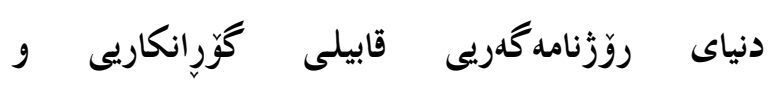

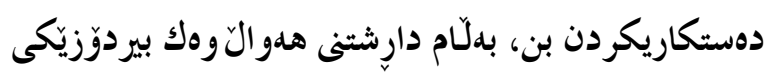

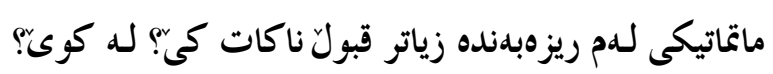

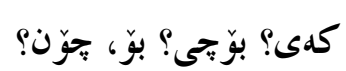

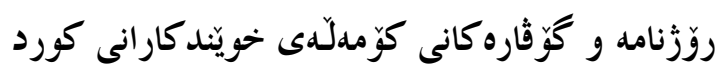

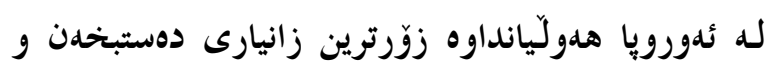
بلّاويان بكهنهوه، كه شوَرِشى ئديلول روويدا، زوَّرترين

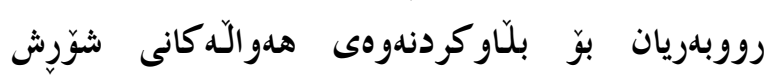

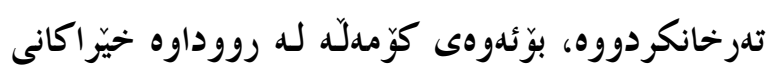

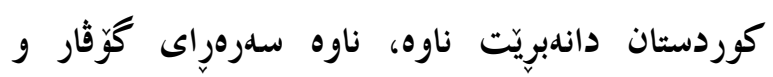

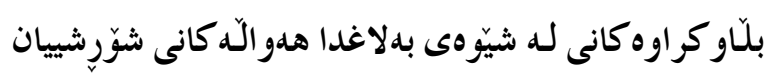

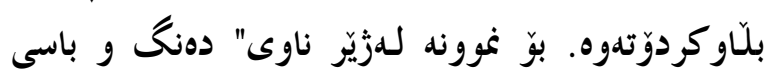

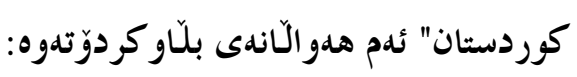

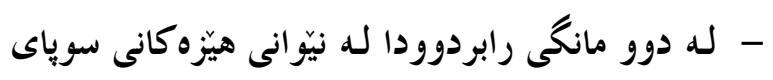

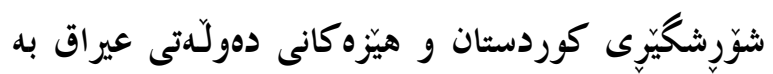

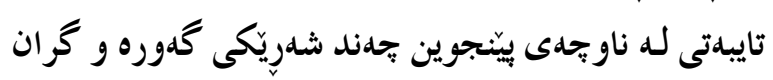




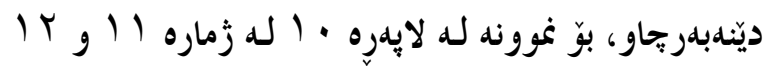

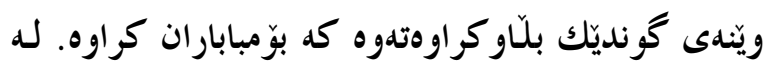

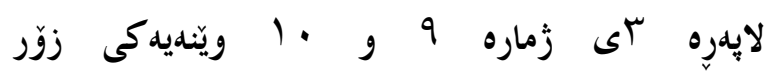

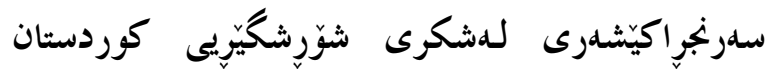

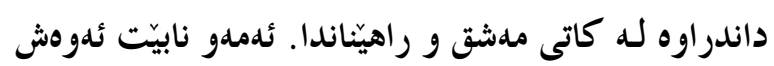

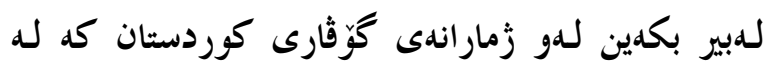

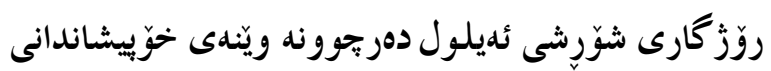

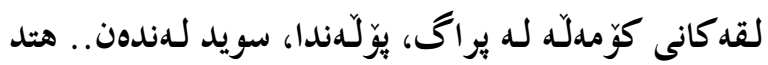

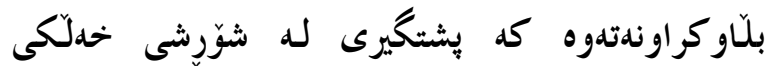

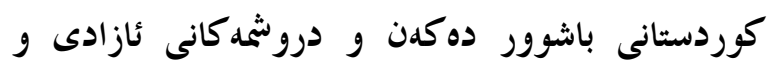
أناشتييان بلهرزكردوّتهوه

هلر سهبارهت به ويَنه دهمهويَت ئامازه به ويَنهيهك

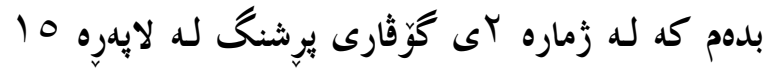

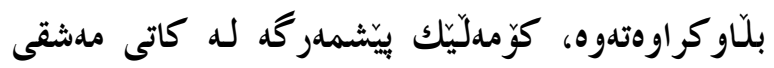
سهربازيدا وهك لـه زَيّر ويَّهكه نووسراوه " هاوينى

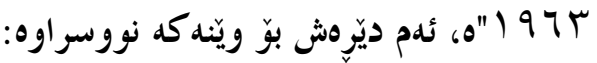

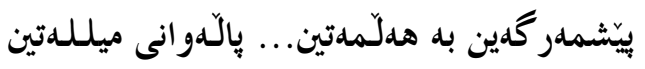

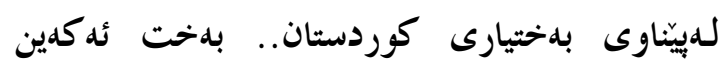
زيانمان مالَ و كيان

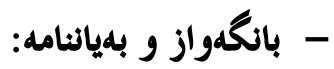

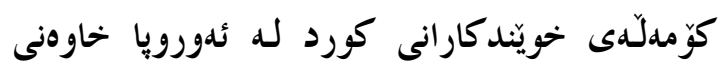

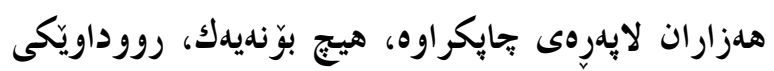

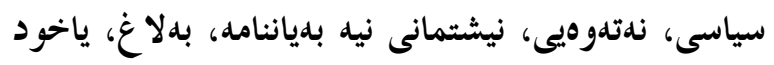

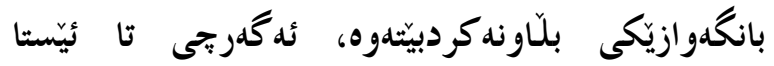

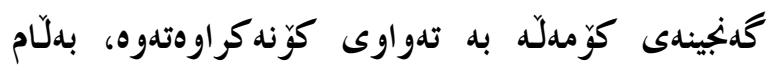

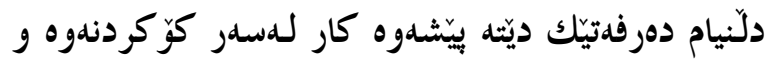

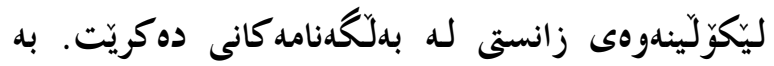

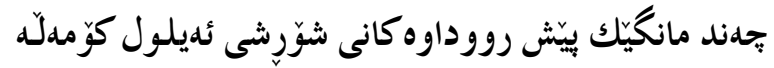

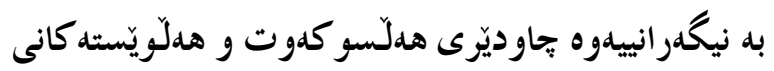
علبدولكهريم قاسم-ى ده كرد، كه روو داوه كهش روويديد

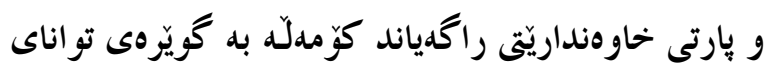

جحهشنى لوَرى تدقييهوه بووه هوَى كوزرانى ه سهرباز و

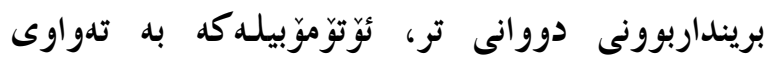

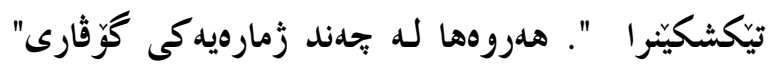

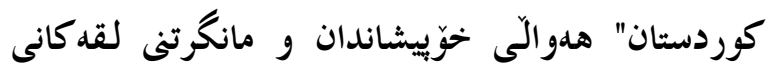

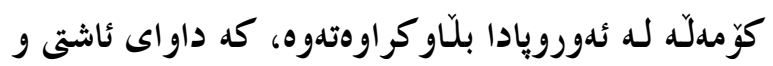

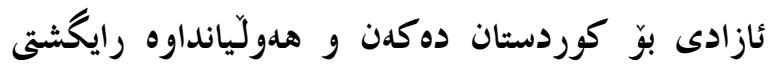

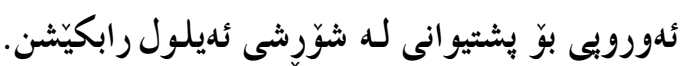
- ميّنه: بلّاو كردنهوهى ويَنه لـه روّزَنامهدا هيجِى كدمتز نيه،

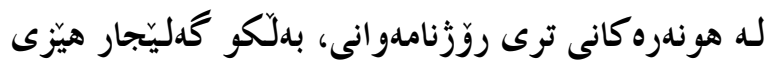

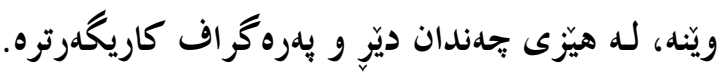

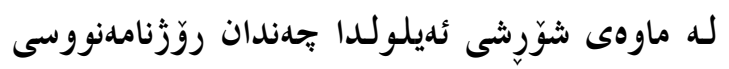
ئيرانى و ئهوروبى سلهردانى بهرهكانى شهر و و ناويجه

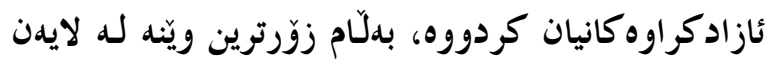

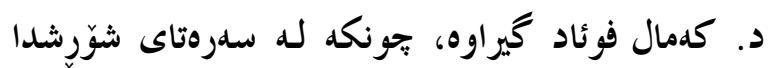
دووجار سلهردانى كوردستانى باشوورى كردووه و سهدان

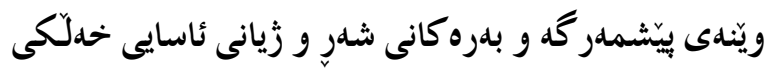

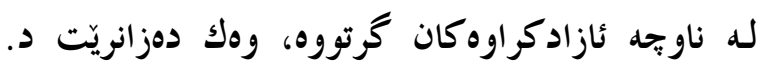

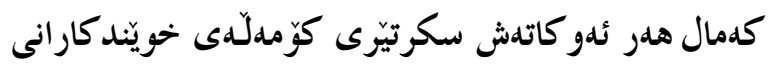

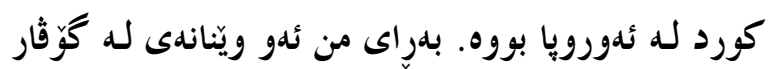

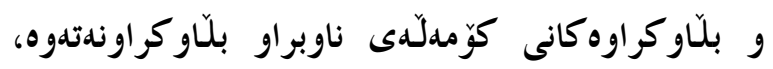

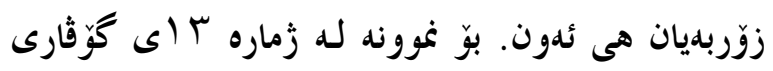

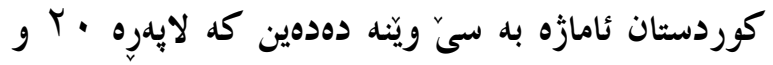

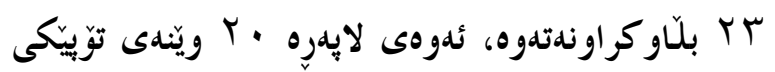

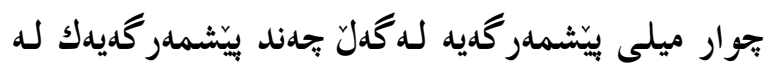

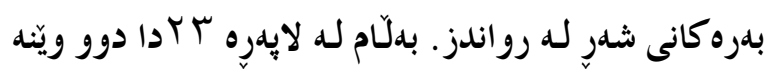

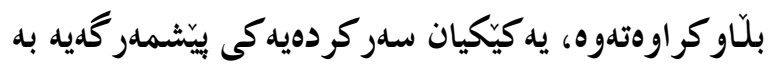

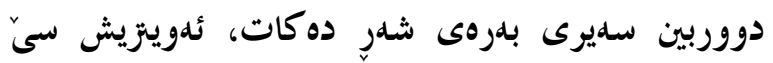

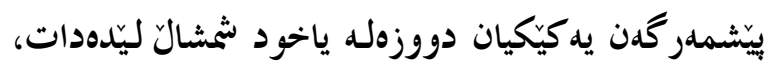

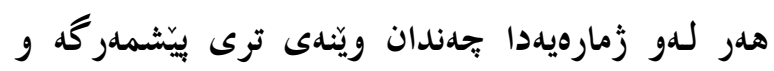

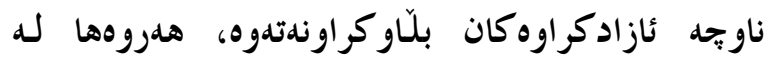

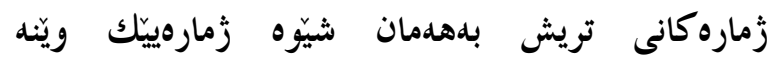




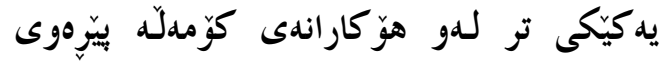

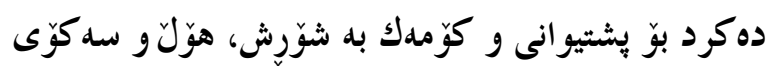

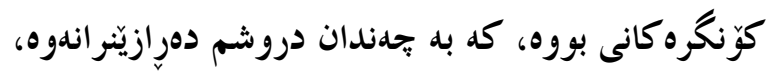

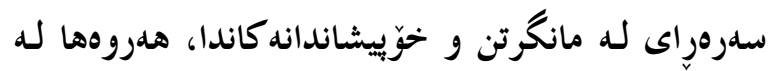

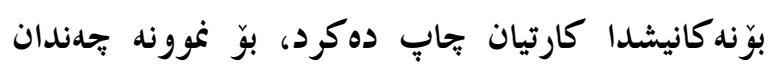

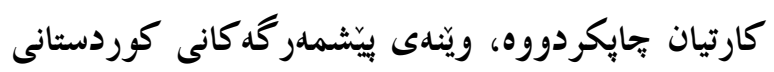

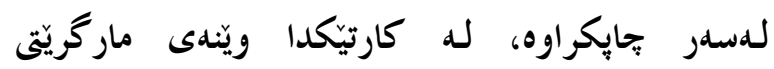

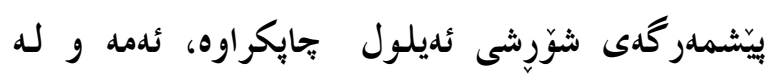

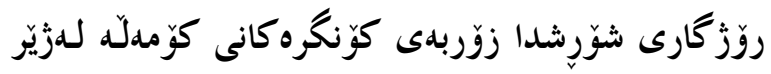

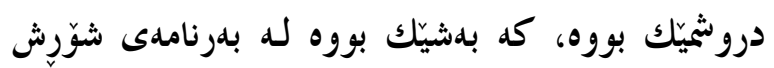

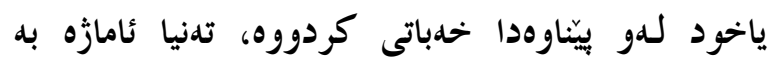
دروشىى دوو كوّنكره دهدهم:

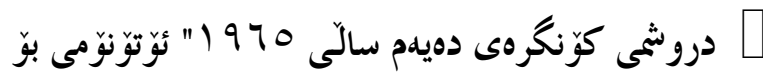
كوردستان و ديمو كر اسى بوّ عيراق.

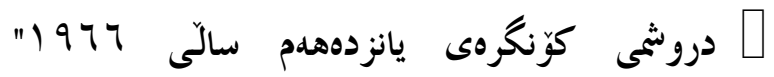
لهييّناوى جارهسهركردنى ئاشتيانهى مهسهلهى كوردي

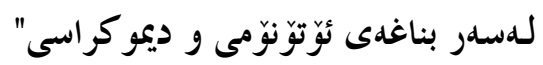

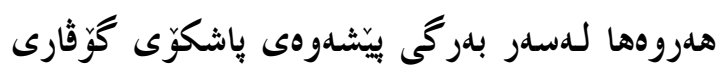

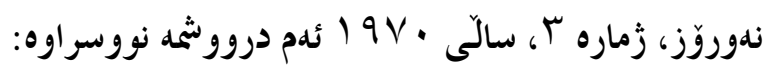

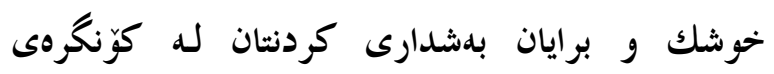

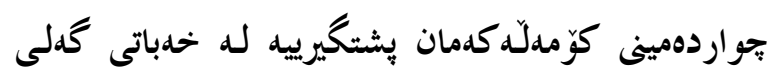

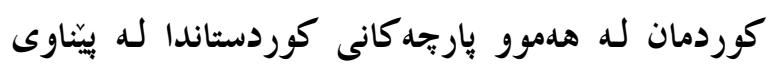

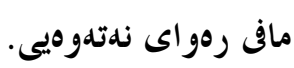

$$
\text { - }
$$

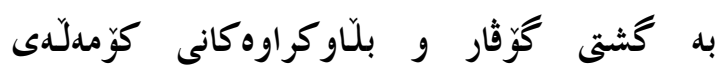

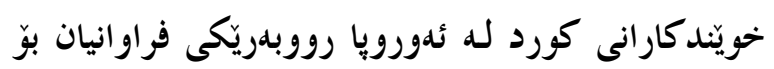

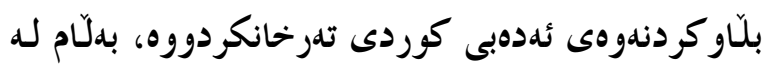

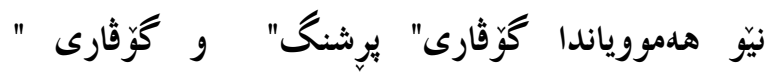
-HEVIYA WELET شوّرشى ئديلولدا ئهو دهقانهى بلّاويانكردوونهتهوه زياتر

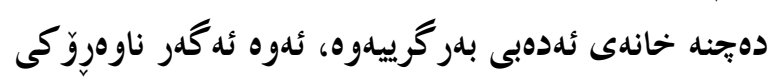

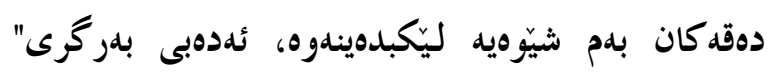

خوّى ئهدهبياتهكانى له خزمهتى شوّرِّه كه دانا، ليّرهدا

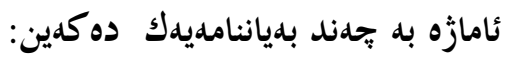

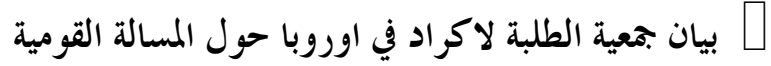
الكردية في العراق... نيسان سج بـ 19

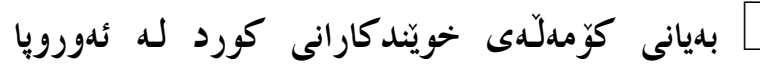

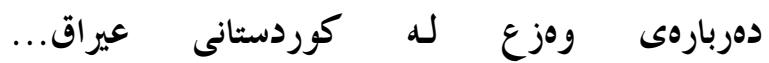
$197 \varepsilon / 14 / 11$

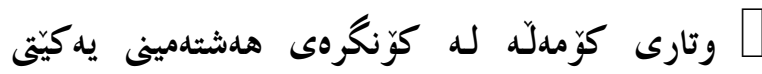

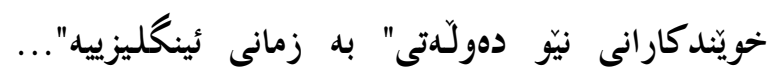

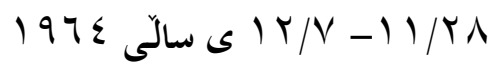
口 الطعية الطلبة الاكراد في اوروثا، بيان الي راي العام العالمي...

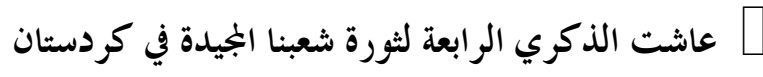
العراق.. 1970/9/11

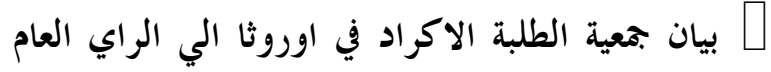
العالمي... $1977 / \mu / 1 V$

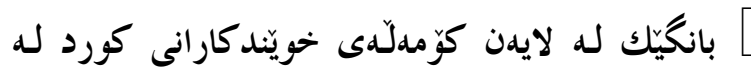

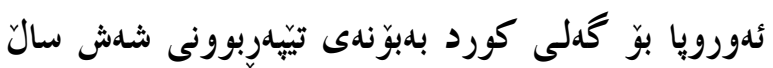

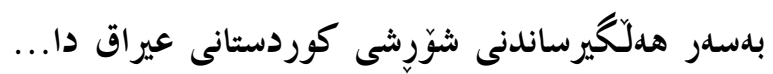

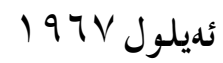
] مذكرة جمعية الطلبة الاكراد في اوروثا الي رئيس

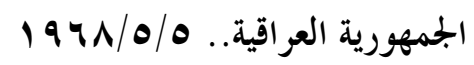

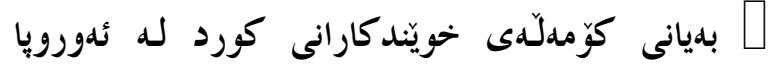

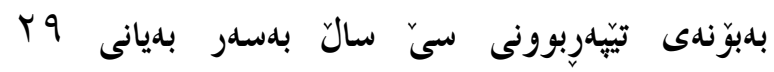

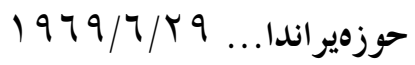

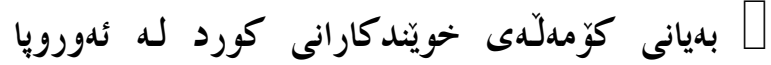

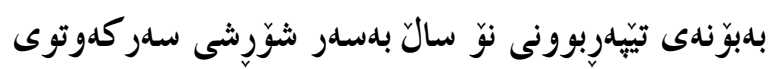
كوردستانى عيراق دا....

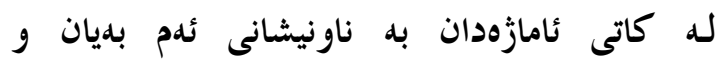
بانكةوازانه رهجاوى ميّزووى دهريجوونيانم كردووه.

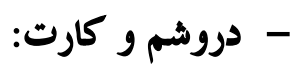




\section{من كَيانى خوّم دايه دهست توّ، توَش ثَازاديم}

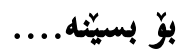

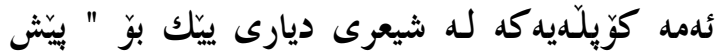

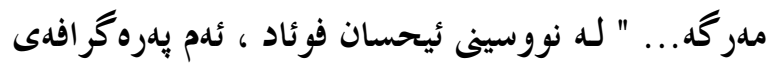

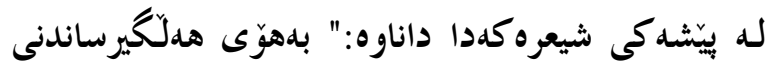

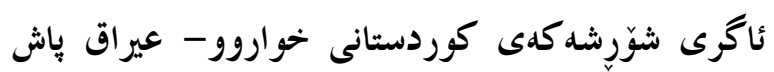

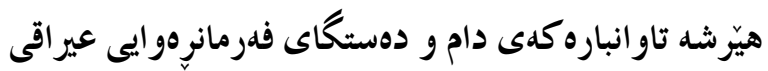
تاو انبارهوه...

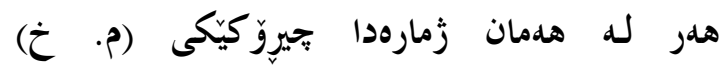

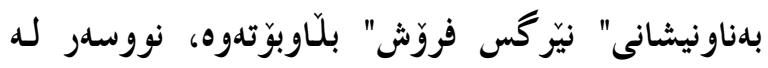

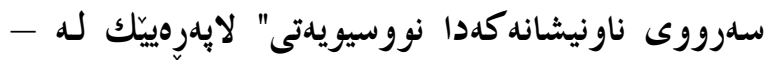

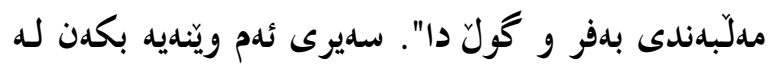

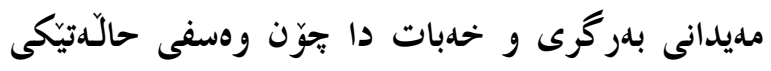

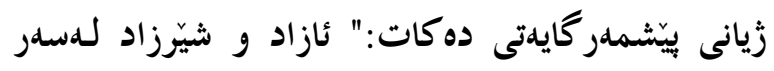

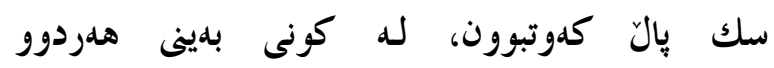

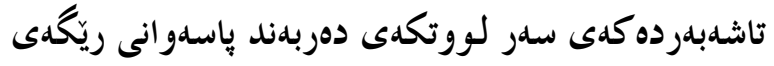

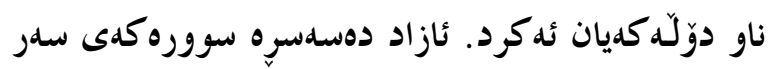

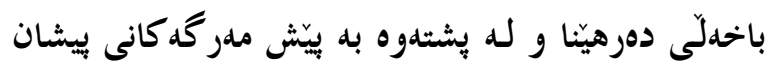

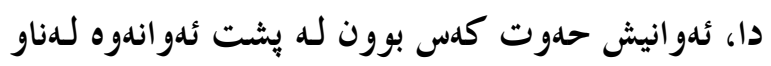

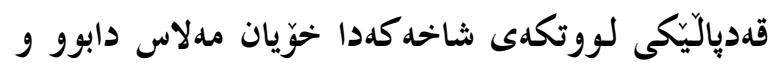

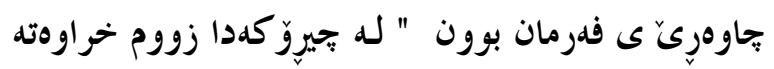

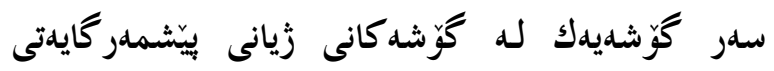

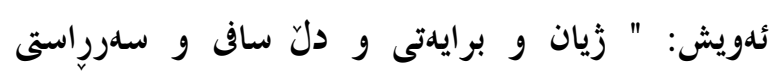

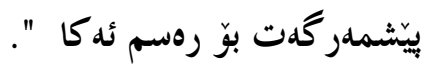

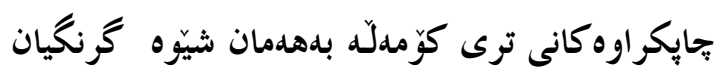

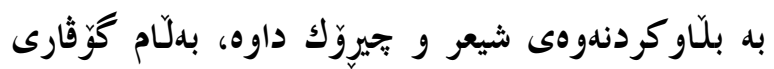

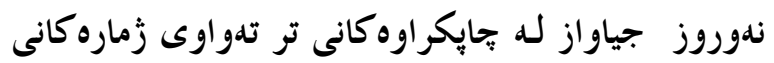

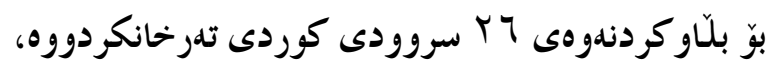

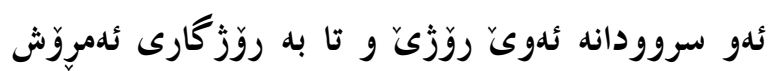

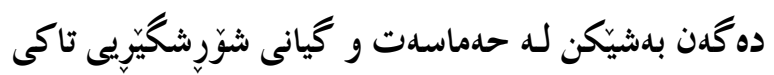

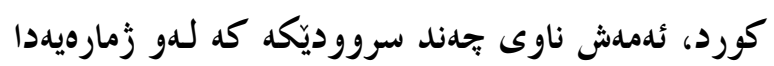
بلّاو كراوندتهوه:" كوردستان، نهوروّز، تحهند شيرينه، كهد

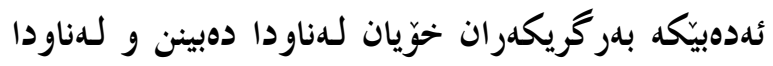
دهيان بينن و هدموو خدلّك هلستيان بيى ده كدن، ئدم

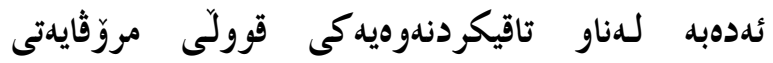

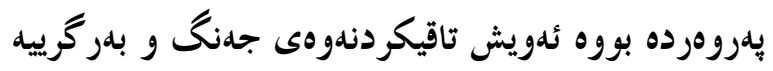

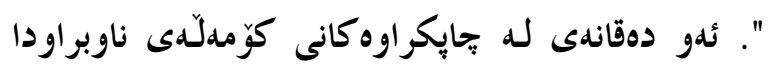

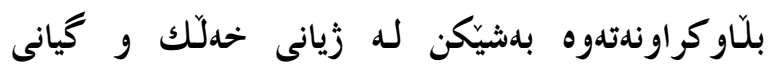
بلهرگرى له ناخى تاكى كورد و خدلّكى كوردستاندا.

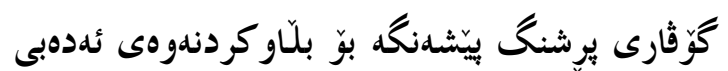

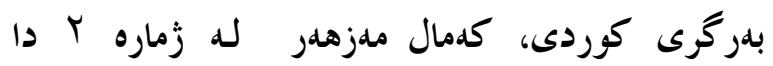

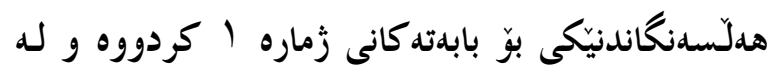

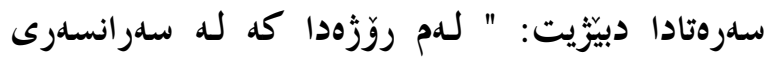

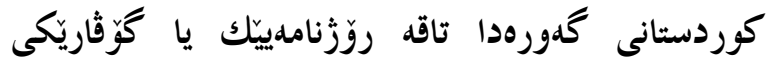

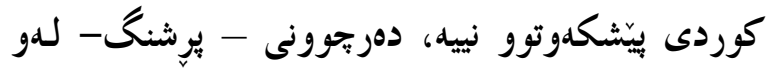

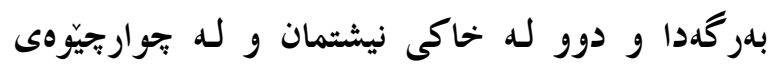

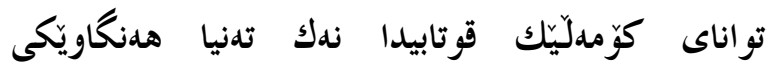

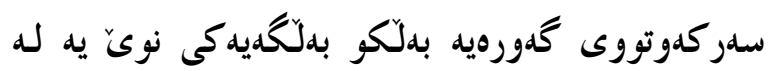
سنوورى خوّى دا كدوا ميللدهتى كورد زيندووه، كهوا

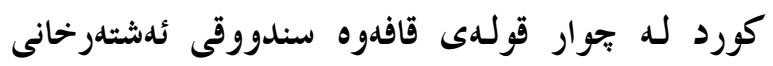

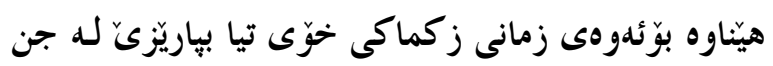

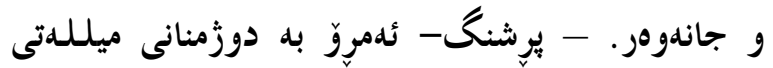

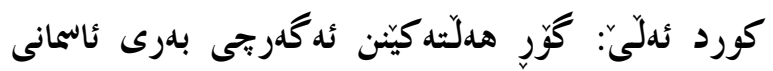

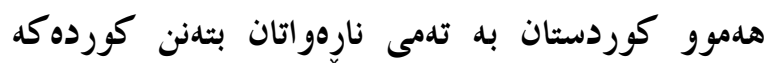

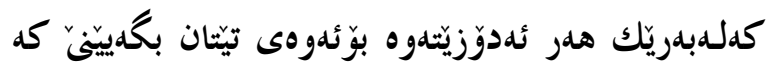

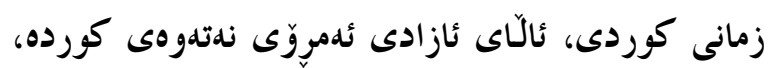

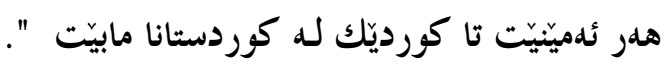

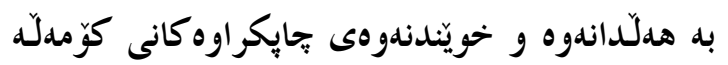

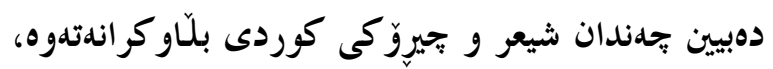

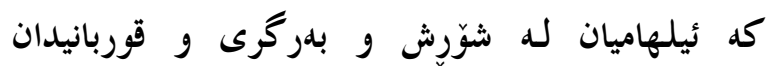

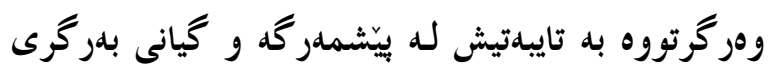

$$
\text { لـه شوَرشى ئديلولدها. }
$$

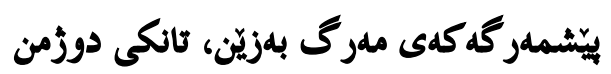

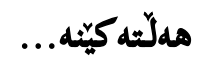




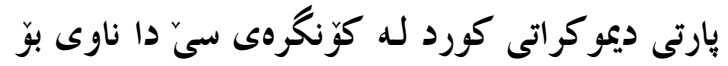

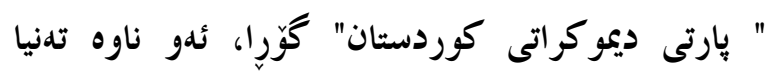

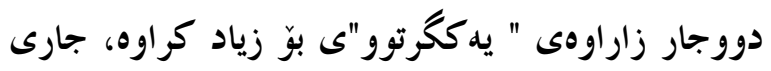

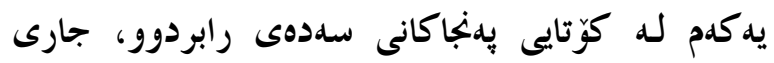

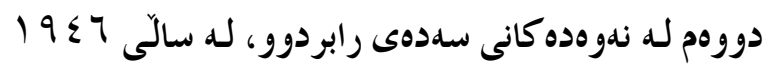

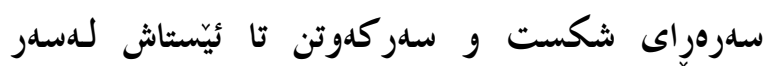
خحباتكر دن بهردهو امه.

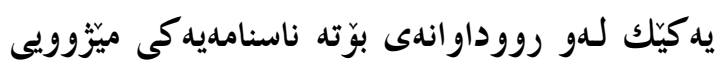

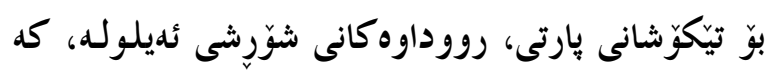

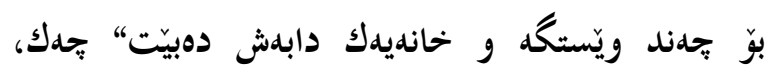

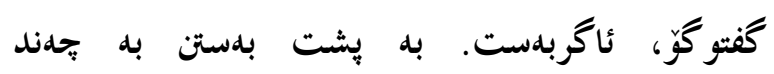

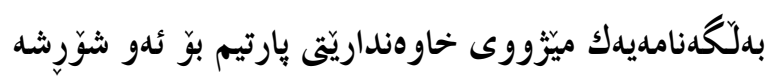
ساغ كردوّتهوه.

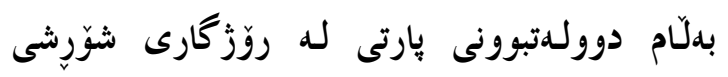

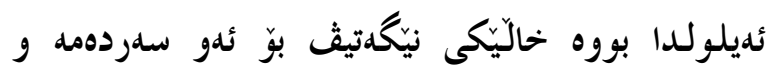

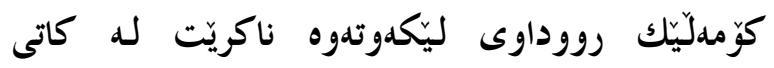
نووسينهوهى ميّزووىى حزبى كوردى فهراموّش بكريّن، به

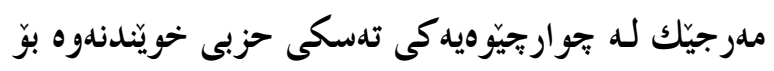

$$
\text { دوولهتبوونه كه نه كريّت }
$$

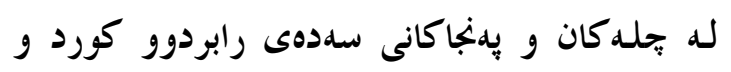

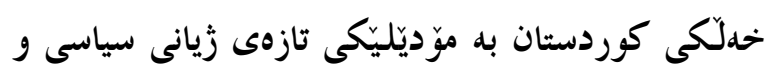

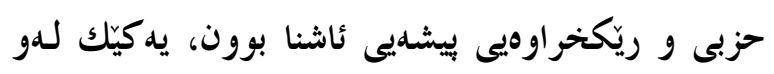

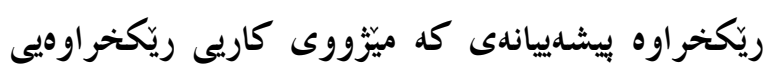

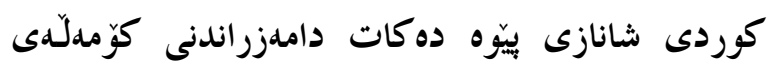

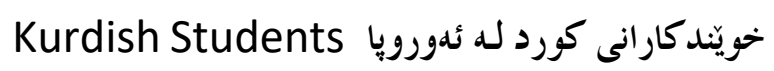

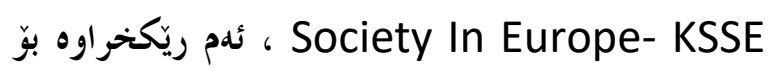
ئهويٌ روّزى سلنتهريّكى درهوشاوه بوو بوّ ناساندنى

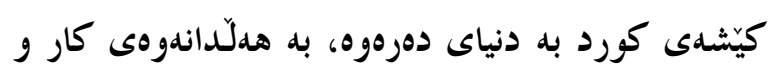

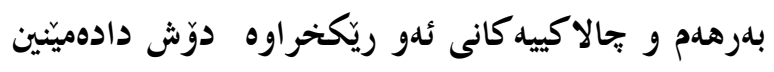

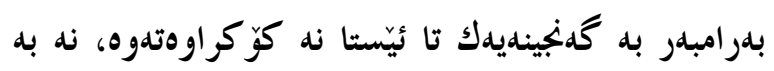

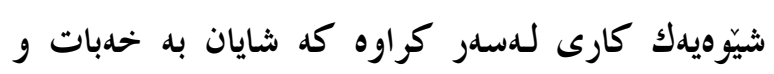

دهلّيّن، دهمى رابِرينه، كوردستان، ئهى قوتابى، سرودى

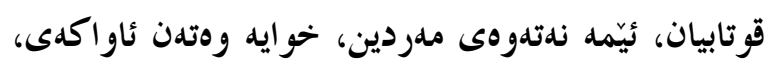

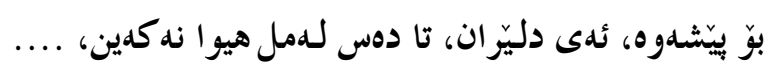

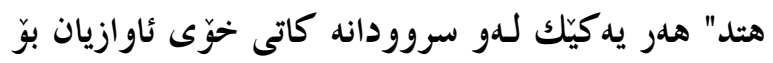
داندراوه و لـه لايهن هونهرمهندانى كورد توّماركراون. بيّوّيست بوو دهستهى سهريلرشتيارانى ئهو زمارهيه ناوى

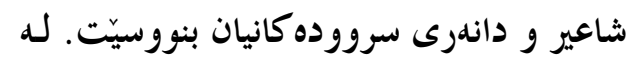

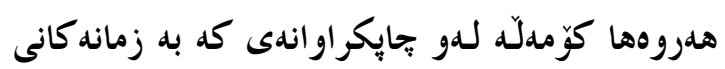

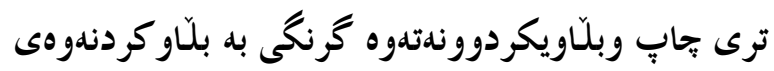

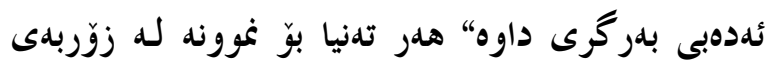

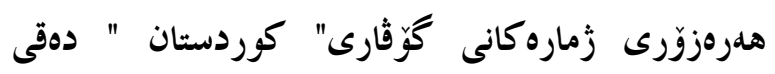
ئهدهبى كوردييان بوّ سهر زمانى ئينگليزى و زمانه كانى

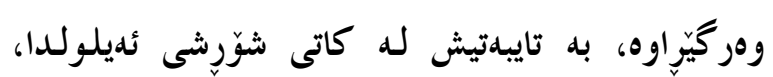

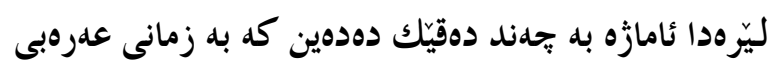

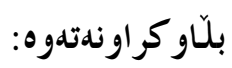
- كردستان موطن الابطال، محمد مهدى الجمواهرى - نوروز، بيرهميرد

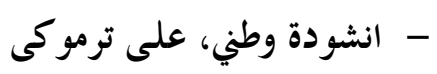
- مصباح قريتنا، مهم

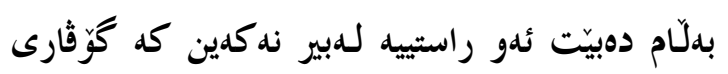

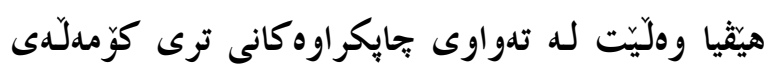

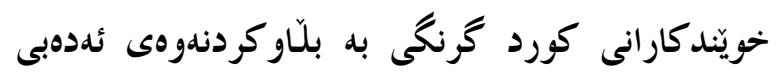

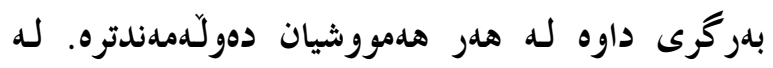

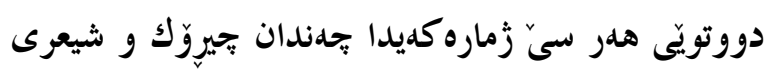

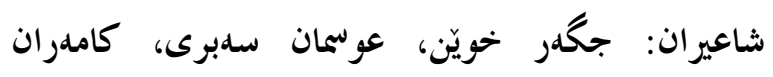

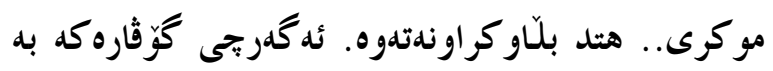
بيتى لاتينى دهرجيووه بدلّام بلّاو كردنهوه

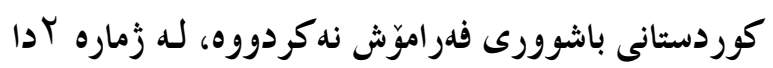
ئهم شيعرهى كامهران بلّاو كراوهتهوه: ثاكر به نلهختى ناو كوزايهوه كولّ به باى بايز سهرى نايهوه 


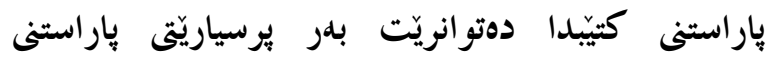

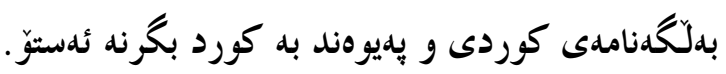

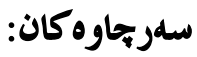

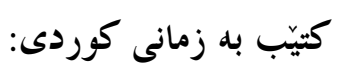

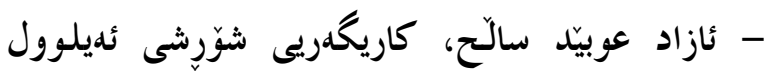

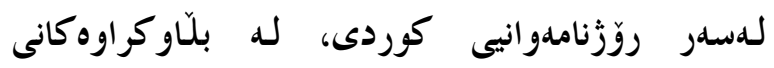

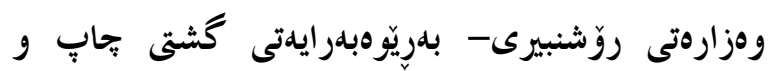

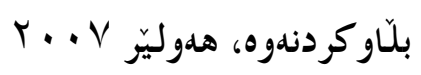

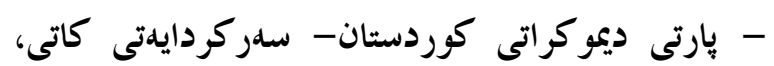

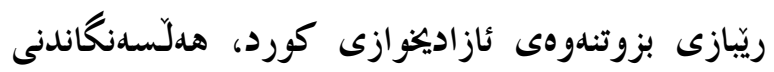

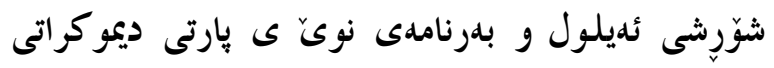

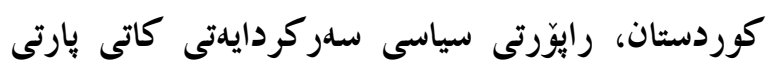

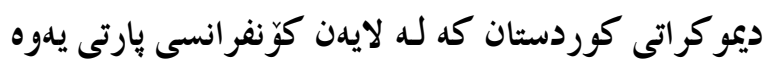

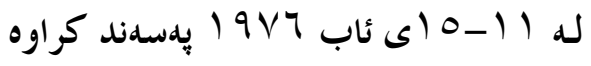

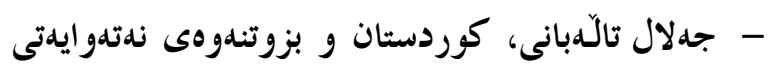

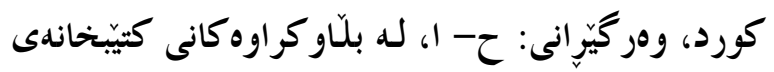

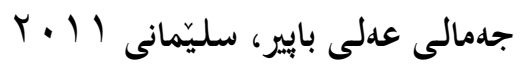

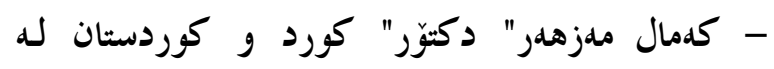

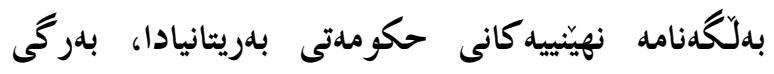

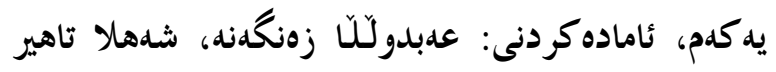

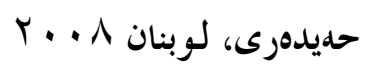

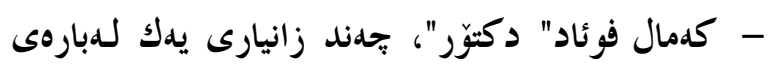

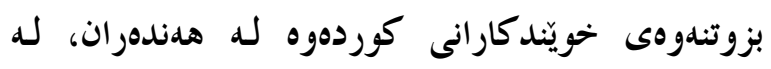

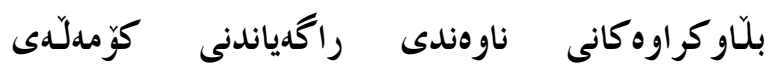

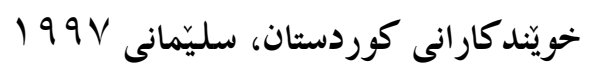

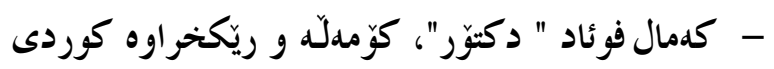

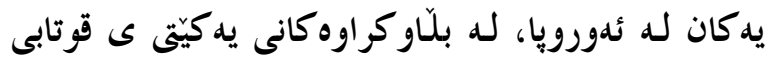

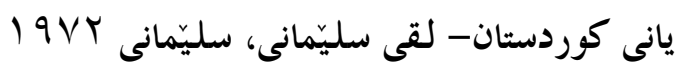

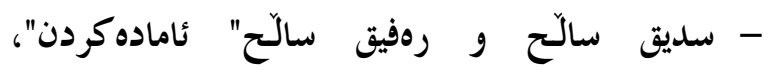

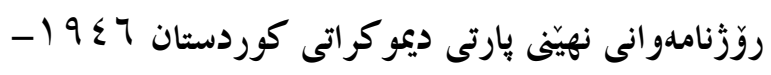

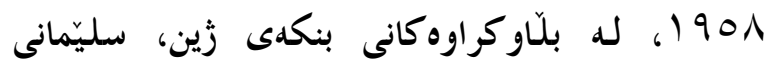

$r .11$
تيّكوّشانى ريّكخراوهكه بيّت. ئدو ريّكخراوه بوّ ئهو

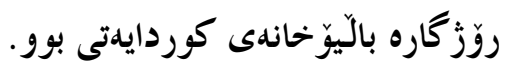

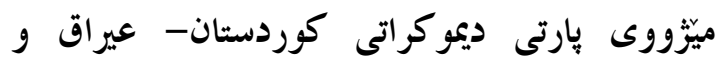

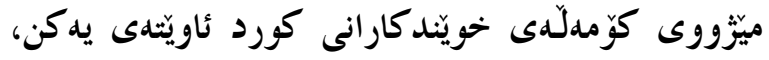

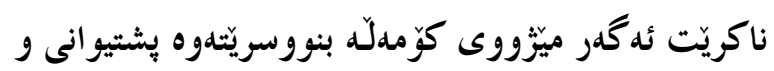
يشتِيريى بوّ شوّرشى ئهيلول فهر اموّش بكريَت.

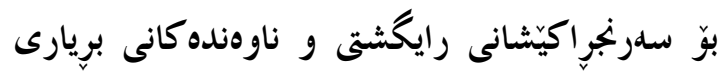

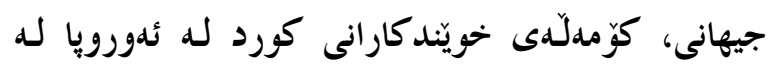

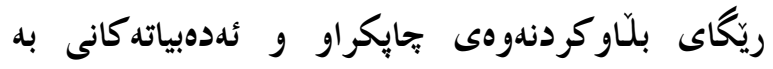

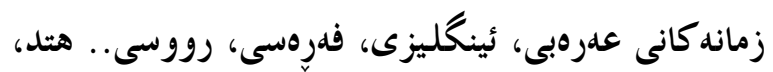

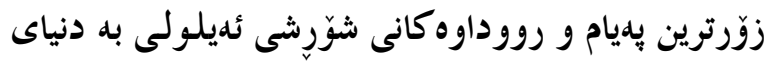
دهرهوه گدياندووه.

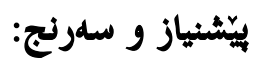

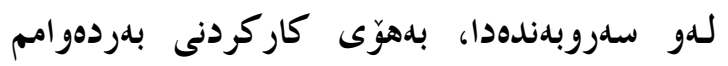

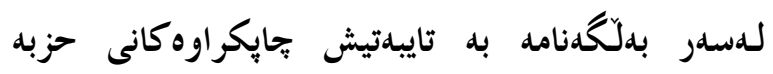

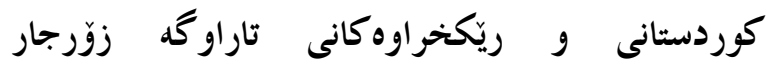

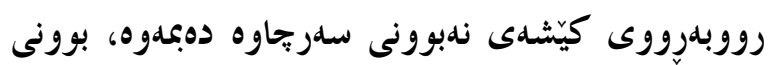

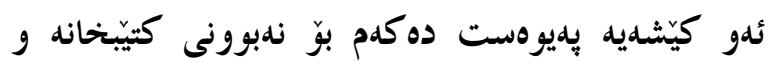

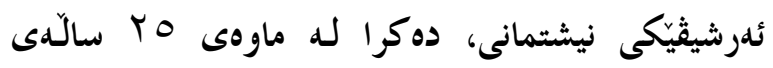

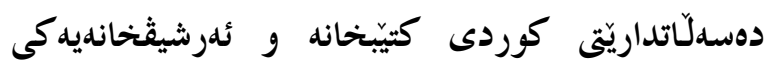
نيشتمانى دابمدزريتا!

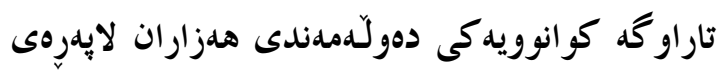

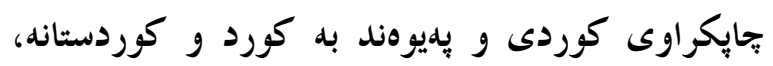

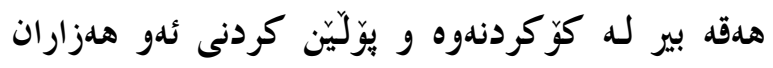

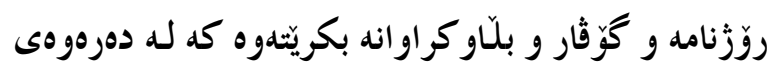

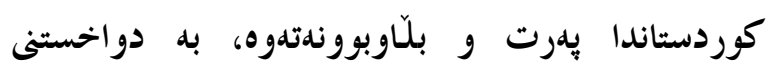

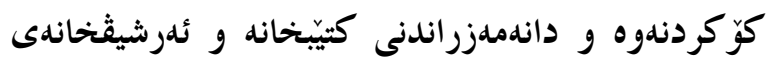
نيشتمانى رهنكه وهك هدزاران لايهرهى تر ئهوانيش بفهوتيّن. هdروها بيِشنيار دهكهم، به برياريّكى وهزارى ناوى

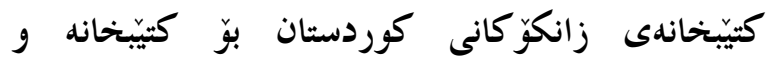

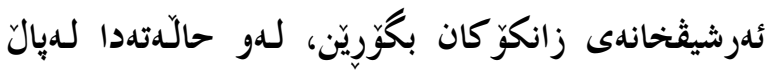




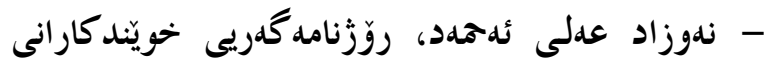

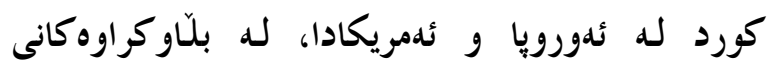

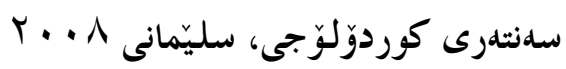
- ندوزاد على ئهمهد، بارتى ديموكراتى كوردستان له له بله

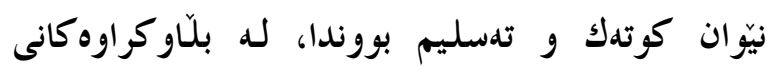

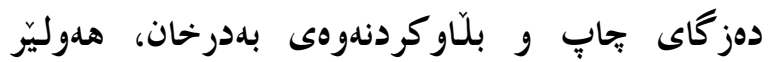
r... 9

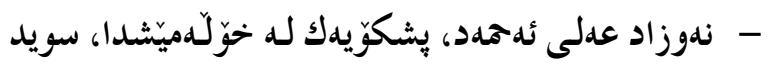
r.l)

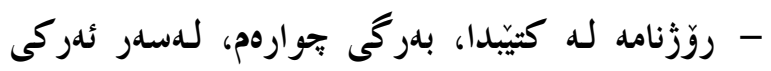

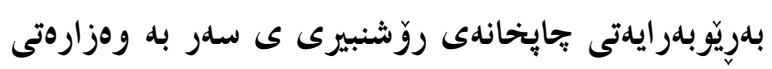

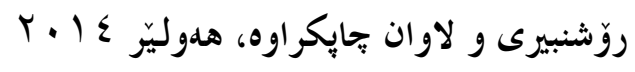

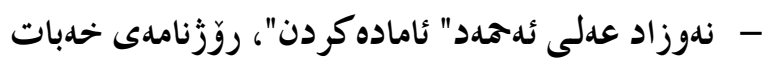
ثئزر كانى بارتى ديموكراتى كوردستان، له بلّاو كراوه كانى لئى

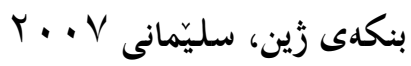

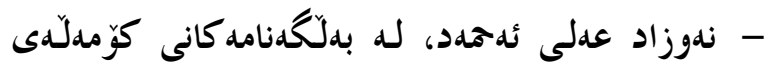

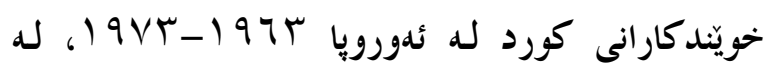

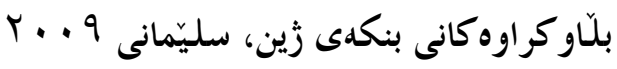

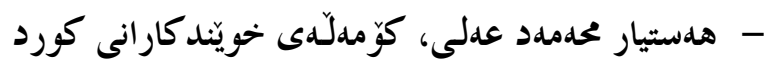

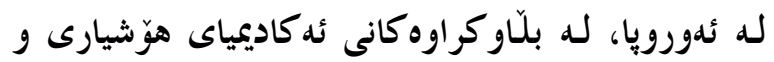

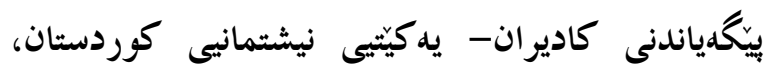

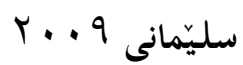

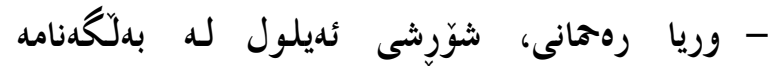

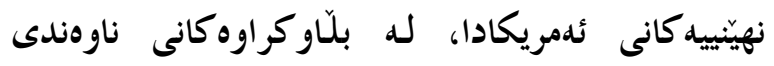

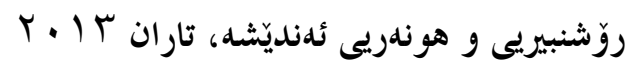
كتيّب به زمانى عهدهبى: - الحزب الديمقراطي الكردستاني- اللجنة التحضيرية،

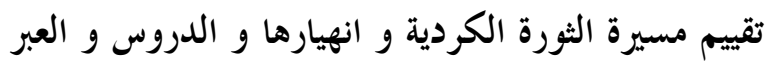
المستخلصة منها، اوائل كانون الثاني $19 V V$

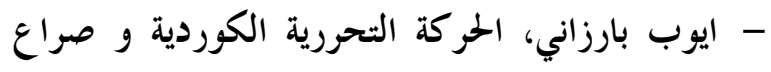

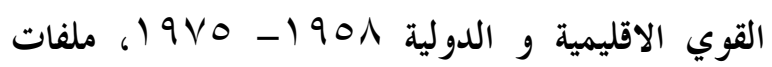

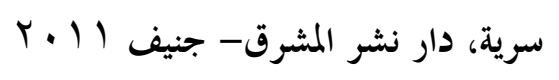

- عارف روشدى عارف، كوّمدلّهى خويّندكارانى كورد

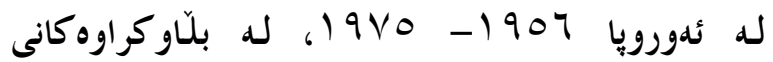

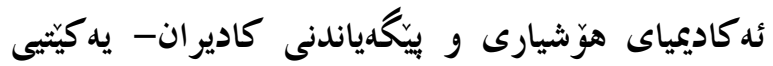

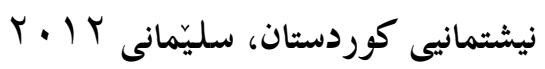

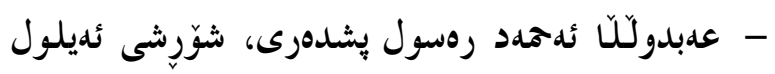

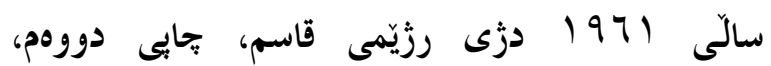

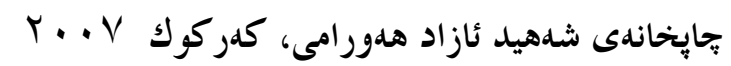

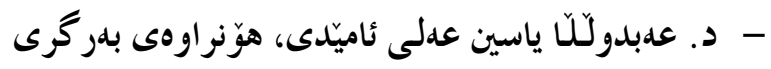

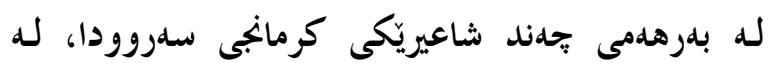

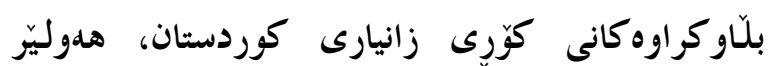
r... - مهسعود بارزانى، بارزانى و بزووتنهوهى رزگگ ماريخوازى

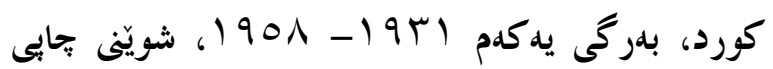

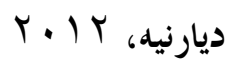
- مهسعود بارزانى، بارزانى و بزووتنهوهى رز كاريخوازى

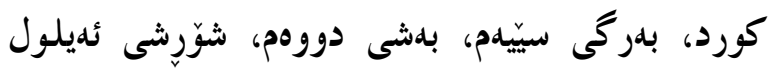

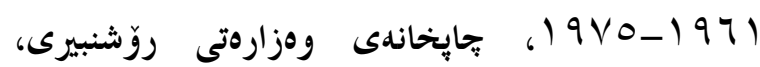

$$
\text { هل }
$$

- موحسين دزهيى، ويّستخدكانى زيانم، سازدانى" تاريق

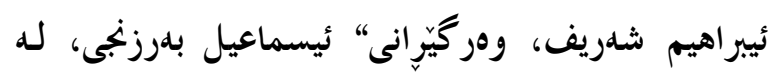

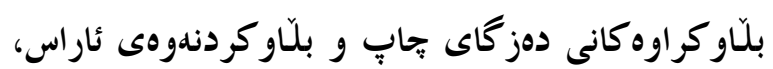

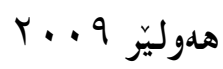

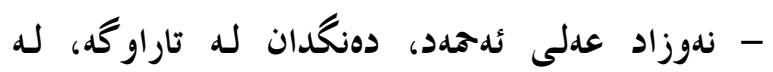

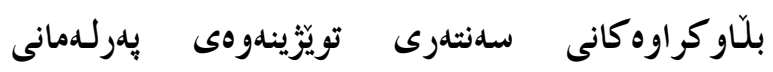

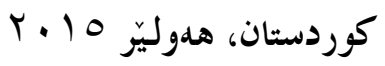

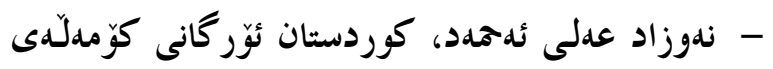
خويّندكارانى كورد له ئلهورويا زَماره ل

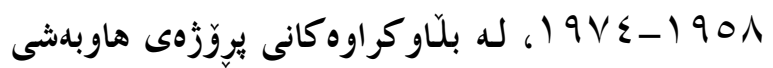

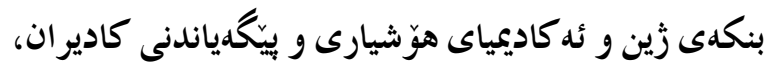

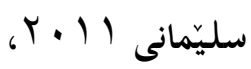




$$
\text { كتيّب به زمانى سويدى: }
$$

SAOB Svenska Akademiens ordbok Flykting (Tryckår 1925 كَّقار و بلحّاو كراوه ZagrosLife $r \cdot 1 \leq$

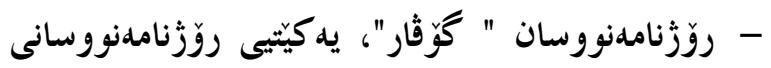

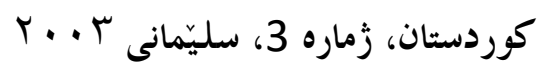

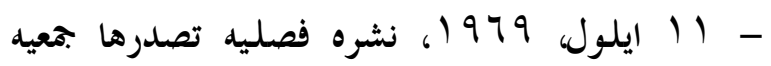

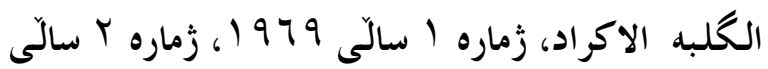
$19 V$. - نوروز، نشره خاصه بمناسبه عيد نوروز- اصدرها فرع جعيد گلبه اكراد في اوربا، زماره HEVYA WELET, Sal 1, jimar 2, Gulan $-1964$

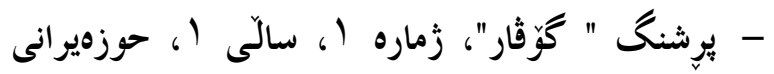

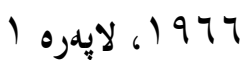

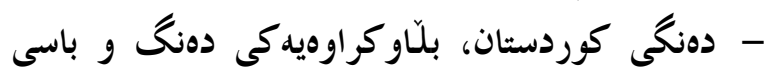

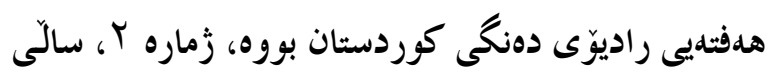

$$
1974 / 1 \cdot 19 \text { ، } 19
$$

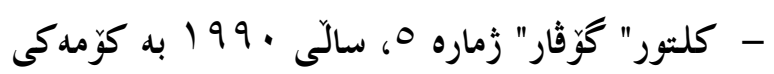
دهز گاى راكدياندنى يدكيتيى نيشتمانيى كوردستان له

شاخ دهرجووه.

$$
\text { سلر:جاوهى تر: }
$$

$$
\text { - كئرشيقى تايبلتى خوّم }
$$

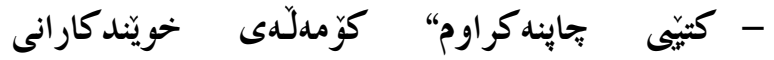
كوردستان له دهرهوهى ولّات-

") $9 \wedge 1$
- شيركو فتح اللة عمر، الحزب الديمقراطي الكوردستاني

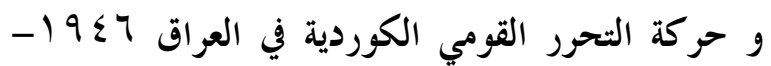

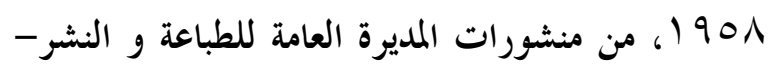

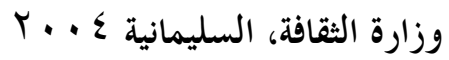
- شيخ علي، اضواء علي الحركة الطلابية الكردية في

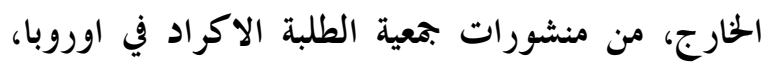

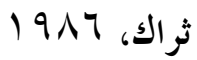

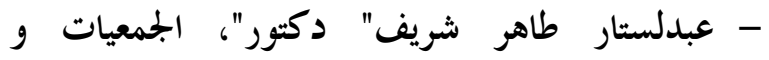

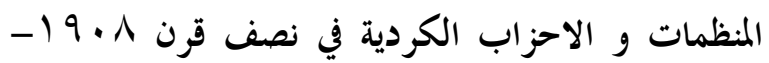

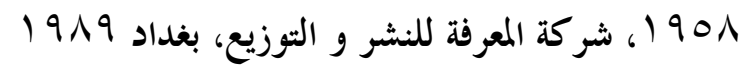
- علي جعفر، كورد المهجر، جمعية الطلبة الكورد في

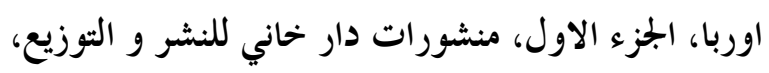
$r .17 \ldots .$. - علي سنجاري، الحركة التحررية الكوردية، مواقف و آ

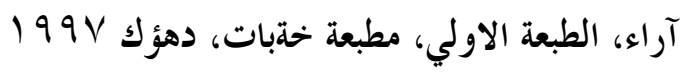

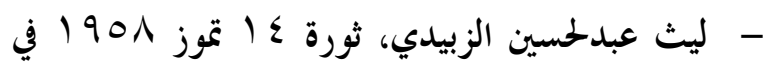
العراق، دار الرشيد للنشر، دار الحرية للطباعة- بغداد $19 \vee 9$ به زمانى ئينگليزى: -Mohamad Salih Karadaghy, KURDISTAN AND KURDS, Kurdish Students Society In Europe( U.K Branch) 1962

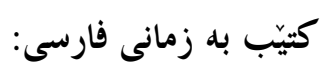

- بهرام ولدبيطي، برتارك طوفان ملا مصطفي بارزاني

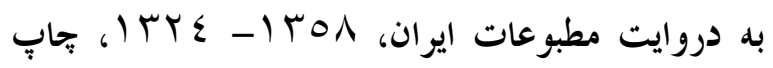

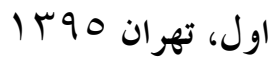
- عرفان قانعي فرد، تندباد حوادث بررسي رخدادهاي

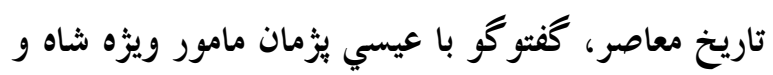

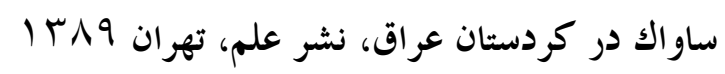




\section{أحداث ثورة أيلول في أدبيات جمعية الطلبة الكورد في أوربا 1961- 1970}

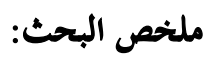

تعرّف الكورد وأبناء كوردستان في أربعينيات وخمسينيات القرن المنصرم واطّلعوا علي نموذج جديد من الحياة السياسية

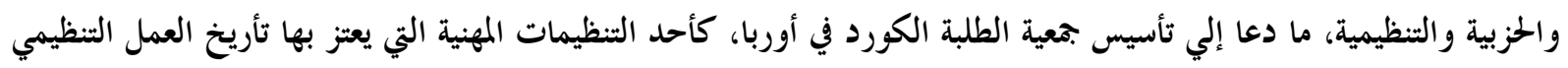

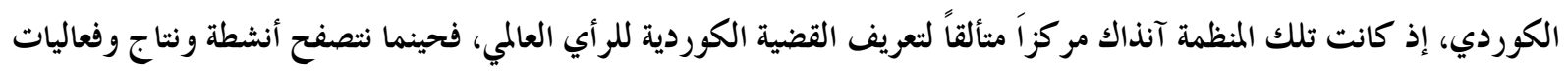

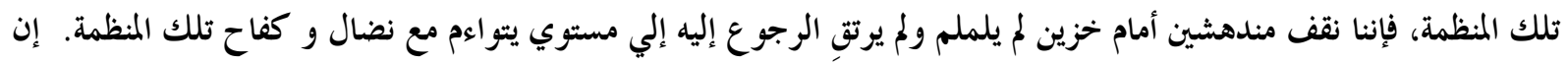
تأريخ الحزب الديمقراطي الكوردستاني-العراق وتأريخ جمعية الطلبة الكورد صنوان، فحينما يكتب تأريخ الجمعية فلا يلا ينبغي إهمال

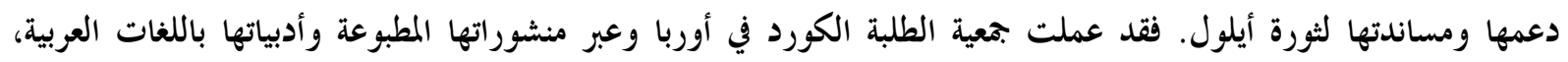

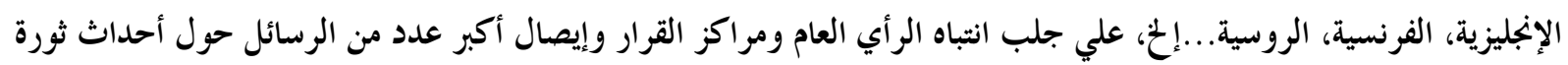

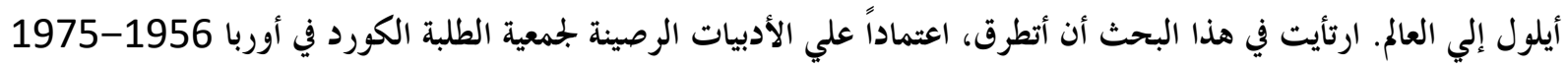

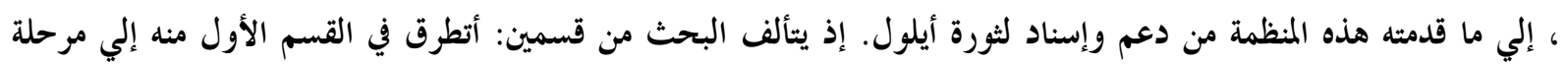

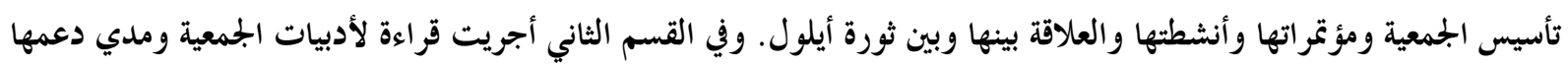
للثورة. وكأي موضوع أكاديمي استفدت من العديد من المصادر التي أشرت إليها في آنفاً.

\section{The History of the September Revolution in the Publications of the Kurdish Students`Society in Europe - KSSE 1961-1970}

\section{Abstract:}

During the 1940's and 1950's of the Twentieth Century, the Kurdish people experienced a new form of organizational, professional and political movements. One of those exemplary professional and interest group associations, that is the center of special Kurdish pride, is the establishment of The Kurdish Students`Society in Europe-KSSE.

This student organization was a vital center for spreading knowledge and information about the Kurdish Question and the Kurdish Movement, abroad. In publishing these materials about the activities, publications and work of this student association, we are amazed at the lack of attention paid to the efforts and struggle of this organization that could do justice to its work and importance. This student organization constituted, in reality, the role of an embassy and a diplomatic representation for the Kurdish National Liberation Movement "Kurdayati ." The history of the Kurdistan Democratic Party in Iraq and the history of the Kurdish Students' Society in Europe are intertwined. Writing a history of KSSE, that does not touch upon its comprehensive and strong support for the September Revolution of 1961 in Iraqi Kurdistan, would be insufficient.

In order to attract and gain the support of international public opinion, the Kurdish Students 'Society in Europe - KSSE distributed most of the news and statements of the September Revolution in many international languages, like Arabic, English, French, Russian, and German, etc. In this research, I have relied mainly on the original documents of KSSE between 1956-1975 concerning their support for the September Revolution in Iraqi Kurdistan. It consists of two parts. In the first part, I deal with the establishment of the student organization, its annual meetings and congresses, its activities as a student organization and its relations with the September Revolution. In the second part, I present a content analysis of the documents and publications of KSSE to ascertain the degree of their support for the September Revolution.

In similarity with other academic works, I have benefited and used multiple sources for my research. The details are presented at the end of the research . 